\title{
Gregorio Sanz, o mestre elocuente
}

\author{
(Gregorio Sanz, the Eloquent Teacher)
}

\author{
Narciso DE GABRIEL \\ Universidade da Coruña
}

\begin{abstract}
RESUMO: Gregorio Sanz García (1900-1997) exerceu como mestre na escola da Fundación Pedro Murias (Vilaframil-Ribadeo), a escola pública de San Pedro de Benquerencia (Barreiros) e a escola preparatoria do Instituto de Ribadeo. $O$ seu compromiso co proxecto transformador da Segunda República e a súa ideoloxía de esquerdas determinou que fose separado do ensino no curso do proceso de depuración a que foi sometido o maxisterio (1937) e condenado a vinte anos de cárcere por un consello de guerra (1938). Na súa traxectoria ocupa un lugar central a defensa da escola pública, que el prefería denominar "escola nacional».
\end{abstract}

PALABRAS CHAVE: Gregorio Sanz García; Segunda República; Franquismo; Depuración do maxisterio; Consellos de guerra; Ribadeo.

ABSTRACT: Gregorio Sanz García (1900-1997) taught at the Pedro Murias Foundation school (Vilaframil-Ribadeo), the public school of San Pedro de Benquerencia (Barreiros) and the secondary school in Ribadeo. His strong commitment to the revolutionary project of the Second Spanish Republic and his leftist ideology caused him to be barred from teaching during the purge of the teaching profession (1937) and sentenced to 20 years in prison after a trial by court martial (1938). His defense of the public school system, which he preferred to call the «national school» occupied a key position throughout his career.

KEYWORDS: Gregorio Sanz García; the Second Spanish Republic; Franco's dictatorship; The purge of the teaching profession; Court martials; Ribadeo.

Logo de presentar, sen entrar en pormenores, o protagonista desta historia, analizaremos o proceso de depuración que sufriu na súa condición de mestre e o consello de guerra que padeceu por mor da súa ideoloxía e militancia de esquerdas. ${ }^{1}$ As principais fontes que se utilizarán son as orixinadas por un e outro proceso represivo, ás que se unen a prensa da época e mais as memorias escritas polo mestre: Uno de tantos. Cinco años a la sombra. ${ }^{2}$

\footnotetext{
${ }^{1}$ Agradezo a Carlos Álvarez Lebredo, Lourenzo Fernández Prieto, José María Lombardero Rico e Helena Zapico Barbeito a lectura deste texto e as valiosas suxestións que me forneceron. Das súas carencias responde unicamente quen o subscribe.

${ }^{2}$ Sada: Ediciós do Castro, 1986.
} 


\section{Entre Benquerencia e Ribadeo}

Gregorio Sanz García naceu en Ayllón, provincia de Segovia, ás dez da noite do 4 de xaneiro de 1900; o seu pai e a súa nai, que se dedicaban á agricultura, respondían aos nomes de Tomás e Antolina. Non sabemos como sería de pequeniño, mais andando 0 tempo, concretamente cando tiña 37 anos, o militar encargado de lle tomar declaración no marco do consello de guerra a que foi sometido describíao así: estatura alta; ollos azuis; pelo rubio; nariz regular; boca regular; e cor clara. ${ }^{3}$

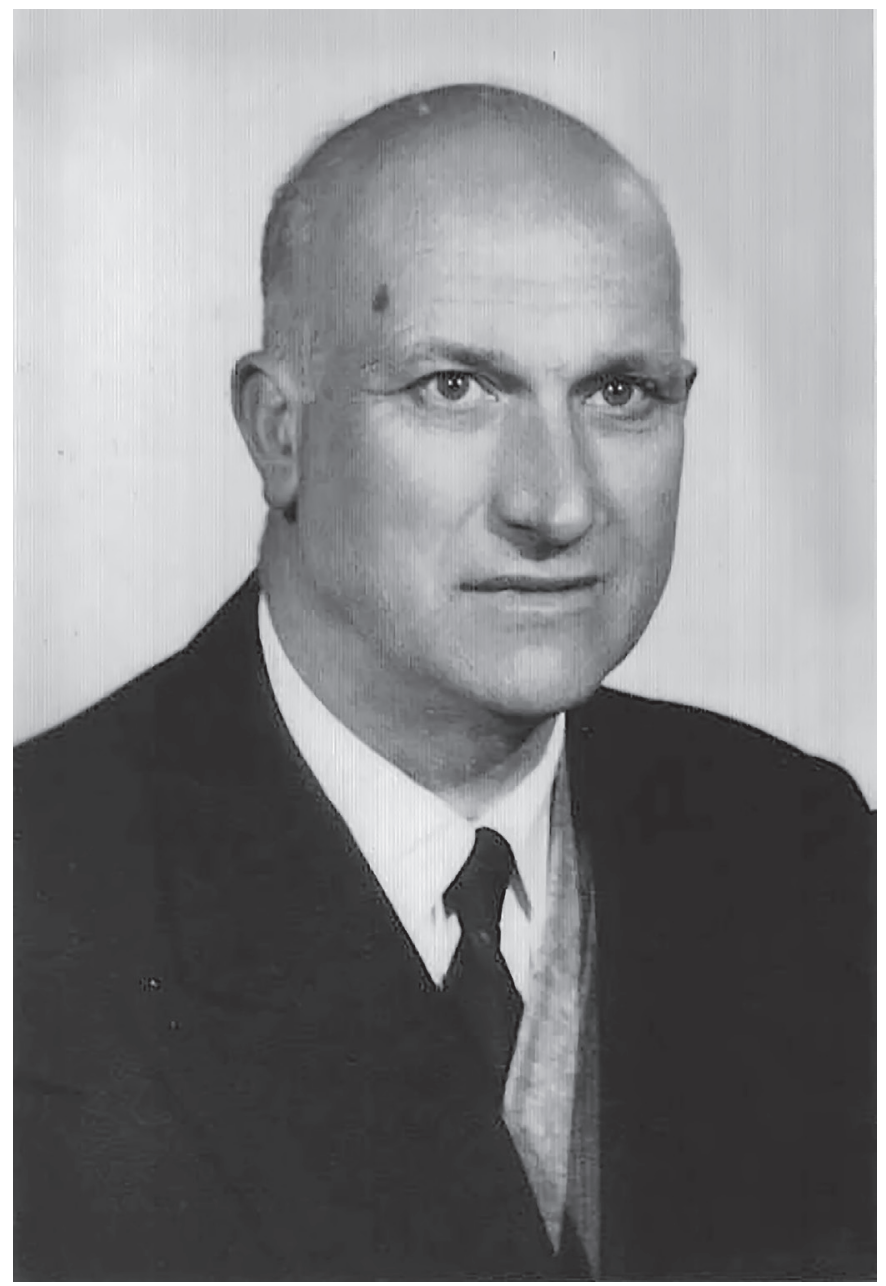

Gregorio Sanz García

${ }^{3}$ Arquivo Intermedio da Rexión Militar do Noroeste. IV Tribunal Militar (Ferrol). Xurisdición de Terra, Fondo Lugo, Caixa 77 , causa 1435/37. 
Como non quería dedicarse á agricultura, optou por cursar Maxisterio, que iniciou en 1914, precisamente no momento en que a carreira pasou a ter unha duración de catro cursos. ${ }^{4}$ Concluíu os estudos aos 17 anos, e dado que aínda era moi novo para exercer como mestre, traballou durante algún tempo nun laboratorio madrileño. En 1918 ingresou no exército, onde acadou o grao de alférez, pero esta circunstancia non lle impediu seguir cultivando os seus coñecementos en materia educativa, pois aproveitaba as tardes para visitar a biblioteca do Museo Pedagóxico, onde coñeceu a Manuel Bartolomé Cossío e a outras persoas relacionadas coa Institución Libre de Enseñanza (ILE). Foron elas as que lle facilitaron os contactos para dar clase no Colexio Concepción Arenal de Madrid, dependente do Protectorado do Neno Delincuente, e foi tamén a través delas como soubo que a Fundación Agrícola Pedro Murias, radicada en Vilaframil (Ribadeo), necesitaba un mestre. Tal circunstancia propiciou que en 1922 aterrase en Galicia, que tiña ganas de coñecer, segundo lle confesou a Antón Costa Rico nunha entrevista realizada en 1992. Estaba previsto que a estadía durase un ano, mais prolongouse durante o resto da súa vida. ${ }^{5}$

Contactara con el Enrique Suárez Couto, enxeñeiro e director da Granxa Agrícola, que comunicara aos seus amigos Indalecio Prieto e Augusto Barcia, vinculados á ILE, a necesidade de contratar un mestre para que se fixese cargo da escola da Fundación. O seu labor como mestre consistirá en iniciar os nenos na aprendizaxe da agricultura e divulgar os novos procedementos agropecuarios entre os agricultores e gandeiros da contorna. ${ }^{6}$ Tratábase, en suma, de pór a granxa e a escola ao servizo da transformación da agricultura e da gandaría, promovendo o seu desenvolvemento e a mellora das condicións de vida das xentes do medio rural. ${ }^{7} \mathrm{E}$ a este labor entregouse Sanz con entusiasmo, polo menos nun primeiro momento, pois Suárez Couto morreu ao cabo dun ano, e os designados para substituílo polo padroado da Fundación, situado na Habana, carecían da súa ilusión, e mesmo «fixeron algún desprecio do meu traballo, que era de mestre de escola e de animador cultural polas parroquias." ${ }^{8}$ Así que en 1927 deixou este emprego e dedicouse a levar a contabilidade de José Acevedo Martínez, alcalde de Ribadeo por aquelas datas, e tamén a dar clases particulares. ${ }^{9}$ Sanz manterá, no entanto, os seus vínculos co mundo agrario;

\footnotetext{
${ }^{4}$ Esta reforma unificou un título que inicialmente tiña tres categorías: elemental (dous cursos de estudo), superior (tres) e normal (catro).

${ }^{5}$ Antón Costa, «Entrevista a Don Gregorio Sanz», Revista Galega de Educación, no. 14 (1992): 66-68. Esta entrevista, xunto cun artigo de Juan Suárez Acevedo («Biografía de D. Gregorio Sanz», Orballo, no. 49, 2007; neste número reprodúcense algúns dos traballos publicados no 24 -1994-, dedicado a don Gregorio, que dá nome ao centro escolar que publica Orballo) e o texto dunha conferencia pronunciada en 2007 por José María Lombardero Rico, constitúen a principal base destas breves notas biográficas.

${ }^{6}$ Reportaxe publicada por J. A. Fariñas en La Voz de Galicia, 29 de abril de 1981.

${ }^{7}$ No seu día examinei algunhas das experiencias animadas por este propósito en Agricultura e escola. Contra a rutina e o éxodo rural (Santiago de Compostela: Servizo de Publicacións da USC, 1989). Unha destas experiencias tivo como principal protagonista a Avelino Pousa Antelo, que deixou constancia dela en A Escola Agrícola da Granxa de Barreiros (Sarria-Lugo) (Sada: Ediciós do Castro, 1988). Véxase tamén Lourenzo Fernández Prieto, Labregos con ciencia (Vigo: Xerais, 1992).

${ }^{8}$ Antón Costa, entrevista citada, 67.

${ }^{9}$ É posíbel que esta última actividade a iniciase antes, pois en 1924 concedéuselle autorización para abrir unha escola privada en Ribadeo (El Pueblo Gallego, 12 de novembro de 1924).
} 
tanto é así, que a Federación Agraria do Partido de Ribadeo designouno secretario —en 1929 creou unha praza remunerada para o desempeño do cargo ${ }^{10}$ e posteriormente nomeouno presidente honorario. ${ }^{11}$

En 1930 aprobou as oposicións para ingresar no maxisterio público. Las Riberas del Eo felicitábao o 4 de outubro dese ano polo seu nomeamento para a escola de San Pedro de Benquerencia (Barreiros); facía saber o 15 de novembro que o mestre e a súa dona, cualificada como «joven y bella», regresaran da viaxe de noivos por varias capitais españolas, e 029 do mesmo mes daba conta da súa toma de posesión da devandita escola. Cando os alumnos do colexio ribadense que leva o seu nome lle pediron en 1994 que contase algunha anécdota da súa traxectoria profesional, confesoulles:

Muchas, pero tal vez lo más significativo de mi forma de dar la clase es que nunca me sentaba, y cuando lo hacía era para ocupar el sitio de un alumno. En el fondo, era un niño más. Cuando llegué a S. Pedro de Benquerencia, hice lo posible por mejorar la enseñanza y una de las primeras cosas que hice fue quitar una barandilla que protegía la mesa del profesor y que impedía a los alumnos acercarse a él. ${ }^{12}$

Na escola de Benquerencia tentará aplicar unha metodoloxía que sintonizase con algúns dos principios da Escola Nova, tal como explica nun texto publicado na madrileña Revista de Pedagogía en 1932. A primeira medida que adoptou consistiu en dotar o centro dunha pequena biblioteca, adquirida coas modestas cotas e o esforzo dos propios nenos, que deliberaron sobre a proposta do mestre, constituíron unha cooperativa e redactaron un breve regulamento para determinar cal sería o seu funcionamento. Deste modo conseguiu suscitar un certo interese pola lectura entre os escolares, e tiña a esperanza de que os libros que estes levaban os sábados para as súas casas fixesen que tamén prendese esta afección nas familias. $\mathrm{O}$ segundo piar do seu proxecto de escola activa foi a adquisición, en réxime de arrendamento, dun terreo de 700 metros cadrados para realizar diversos cultivos. Este recurso, ademais de permitir a práctica da observación e a experimentación, propiciaba outras actividades e aprendizaxes: redactar un contrato de arrendamento, escribir cartas para solicitar fertilizantes, decidir os cultivos que se realizarían ou adquirir as sementes, plantas e ferramentas necesarias. ${ }^{13}$

Dous anos máis tarde, en 1932, fíxose cargo da escola preparatoria do Instituto de Ribadeo, que fora creado en 1928. No mes de novembro, cando iniciou as clases, a matrícula ascendía a máis de trinta nenos e nenas. ${ }^{14}$ Un dos seus alumnos foi Víctor Moro, en cuxa

\footnotetext{
${ }_{10}$ El Progreso, 13 de febreiro de 1929.

${ }^{11} \mathrm{O} 13$ de abril de 1932 presidiu, en ausencia do presidente, a reunión da Federación. Na nota que publicaron sobre 0 acto os agrarios aludían ao agarimo que lle tiñan os labregos e lamentaban asemade que a súa actuación non tivese máis imitadores no maxisterio (El Pueblo Gallego, 26 de marzo de 1932).

12 Entrevista realizada por Naomi Álvarez Lillo, María José García Piñeiroa, Beatriz Fojo Pérez e Nacho Fernández Díaz, publicada no número 24 da revista escolar Orballo, xa citada.

${ }^{13} \mathrm{O}$ texto foi reproducido por Antón Costa Rico, por quen citamos: Escolas e mestres. A educación en Galicia: Da Restauración á Segunda República (Santiago de Compostela: Xunta de Galicia, 1989), 457-460. Cando abandonou Benquerencia, os veciños ofrecéronlle un sentido acto de despedida (Las Riberas del Eo, 26 de novembro de 1932).

${ }^{14}$ Las Riberas del Eo, 26 de novembro de 1932.
} 
memoria permanecen vivas as excursións escolares, que lle permitiron ver o nacemento do río Miño e seguramente albiscar a lingua das bolboretas,${ }^{15}$ mais tamén permanece 0 traballo continuado do mestre na aula: "Todos los días nos sorprendía con renovadas ilusiones. No transcurría jornada en que nuestras mentes no se abrieran a un nuevo conocimiento. No desperdiciaba oportunidad para la conformación de nuestras voluntades en el estudio consciente y en el desarrollo de la más completa colaboración y confraternidad. ${ }^{16}$

Don Gregorio foi presidente da Asociación de Mestres do Partido Xudicial de Mondoñedo, e na entrevista que lle fixo o profesor Antón Costa lembraba o traballo cooperativo realizado con algúns compañeiros da bisbarra, que se reunían as tardes dos xoves, de forma rotativa, na escola dun deles para observar como ensinaba e discutir posteriormente cuestións de carácter metodolóxico. "Nunha destas reunións surxíu a idea de editar un periódico escolar de varias clases (El Pequeño Escolar), ligado á idea da imprenta na Escola, e queriamos conquerir que os mesmos nenos o imprimiran anque non chegamos a elo. Non nos deron tempo. Os orixinais que eu levaba á imprenta eran de escolas de $\mathrm{S}$. Miguel, de S. Cosme, de Trabada, da Pontenova... ${ }^{17}$

Xosé Ramón Fernández Oxea, máis coñecido como Ben-Cho-Shey, salientará, nun artigo titulado "Renegados e progresistas", a sintonía do noso home co galeguismo. ${ }^{18}$ Logo de criticar os mestres galegos que renegaban do idioma propio de Galicia, gababa os nacidos fóra dela que o aprendían e usaban, dos que citaba dous: 0 aragonés Gregorio Borao Valero, mestre das Negradas (O Vicedo), que defenderá o bilingüismo escolar no Congreso Pedagóxico que tivo lugar na Coruña en 1927, «cousa que non foi capaz de facer ningún escolante galego", e Gregorio Sanz García, "que fala i escribe o galego millor que ises renegados que coidan que a redención de Galicia solo depende da súa castelanización, i eu recibo e gardo con agarimo i estimanza as cartas que decote me escribe na nosa fala. ${ }^{19}$

Ao longo destes anos pronunciou conferencias e impartiu leccións sobre diversos temas, tanto no período ditatorial como no republicano: no Ateneo de Ribadeo tratou sobre a situación das mulleres; ${ }^{20}$ a Biblioteca Popular Circulante de Castropol convidouno a disertar sobre "La escuela de hoy»,21 nos cursiños de selección do maxisterio realizados na capital da provincia desenvolveu unha lección modelo sobre a iniciación dos

\footnotetext{
15 "A lingua das bolboretas" é o título dun relato de Manuel Rivas -e da película homónima de José Luis Cuerda - incluído en Que me queres, amor? (Vigo: Galaxia, 1995), 21-34, que ten en Uno de tantos unha das súas fontes de inspiración. Véxase María Eugenia Bolaño Amigo, «Cinema, República e Escola en Galiza. Cando os nenos observaban A lingua das bolboretas", Educació i Història. Revista d'Història d'Educació, no. 33 (2019): $179-200$

${ }_{16}$ Prólogo a Uno de tantos, 6.

${ }^{17}$ Antón Costa, entrevista citada, 67.

${ }^{18}$ En Uno de tantos (páxinas 152-155) reprodúcese un artigo de Ben-Cho-Shey titulado «As bágoas do escolante» e dedicado "A tódolos escolantes que choraron», que trata sobre a depuración e persecución do maxisterio.

${ }^{19}$ La Noche, 24 de xuño de 1964. O seu afán por perfeccionar o idioma galego manterase no tempo: La Voz de Galicia informaba 07 de setembro de 1978 que aprobara o curso deste idioma programado polo xornal coruñés.

${ }^{20}$ El Progreso, 11 de decembro de 1923.

${ }^{21}$ El Pueblo Gallego, 1 de abril de 1927.
} 
nenos na numeración e outra acerca dos nomes e os adxectivos;, 22 na Festa da Saúde organizada polo Consello Local de Primeiro Ensino o 28 de maio de 1934 ocupouse dos problemas da hixiene escolar; ${ }^{23}$ nos cursiños promovidos polo Ateneo-Biblioteca Popular para os obreiros e os fillos dos socios encargouse das clases de xeografía humana; e no Círculo Habanero da Devesa abordou o cooperativismo agrario en 1933 e o proceso de formación da terra en $1936 .{ }^{24}$ Tamén foi el quen presentou o grupo de teatro «La Barraca» cando actuou en Ribadeo en 1932, precedendo no uso da palabra a Federico García Lorca. ${ }^{25}$

Participou, así mesmo, en múltiples iniciativas de carácter cultural —José María Lombardero Rico afirma que foi «un dos máis importantes dinamizadores da vida cultural ribadense»-,${ }^{26}$ entre as que salientaremos a creación da Biblioteca Popular Circulante. Nun manifesto titulado «Por la cultura popular» e asinado por Camilo Barcia Trelles e outras cinco persoas, entre elas a que nos ocupa, solicitábase a colaboración dos ribadenses do interior e da diáspora nesta benéfica empresa. ${ }^{27}$ Certo é que xa existía unha no Ateneo, pero era de pagamento e estaba destinada unicamente aos seus socios, mentres que a proxectada tiña un carácter aberto e gratuíto, ${ }^{28}$ pretendía complementar e dar continuidade ao labor realizado pola escola primaria e estaba animada por un triplo afán: permitir que as persoas puidesen adquirir coñecementos de utilidade para o exercicio dos seus respectivos oficios e profesións, promover a súa formación como cidadáns e ofrecerlles a posibilidade de gozaren das obras literarias. Pretendíase, ademais, instalar sucursais noutras localidades próximas, seguindo o exemplo da biblioteca do mesmo carácter existente en Castropol, que o manifesto presentaba como modélica. Así se fará: en 1932 inaugurouse unha sucursal en Santiago de Reinante, que era a segunda, ${ }^{29}$ e en 1933 outra en San Miguel de Reinante. ${ }^{30}$

\section{Detención e cárcere}

O 18 de xullo de 1936 o mestre gozaba das vacacións de verán na vila de Ribadeo. É posíbel que algúns días máis tarde tivese previsto encamiñarse cara a Ayllón en compañía da súa muller, Teresa Sánchez Pulpeiro, para pasar alí o resto das vacacións, como adoitaban facer.

\footnotetext{
22 El Progreso, 2 e 4 de febreiro de 1932.

${ }^{23}$ Las Riberas del Eo, 26 de maio e 2 de xuño de 1934.

${ }^{24}$ Ibídem, 20 de maio de 1933 e 9 de maio de 1936.

${ }_{25}$ Carlos Álvarez Lebredo, La Comarca del Eo, 22 de setembro de 2007.

${ }^{26}$ Sociedade Ribadense (1900-1936) (Ribadeo: Editorial Nigoboa, 1999), 59.

${ }^{27}$ El Progreso, 13 de outubro de 1927.

${ }^{28}$ Sanz, que por esas datas era o bibliotecario do Ateneo, propuxo que se permitise «a entrada libre na biblioteca de calquera ribadense e a supresión da cota polo servizo de préstamo. Como a súa proposta foi rexeitada, en colaboración cun grupo de amigos, fundaron a Biblioteca Popular Circulante» (Lombardero, Sociedade Ribadense, 77-78). Ambas as bibliotecas fusionáronse en 1927.

${ }^{29}$ Las Riberas del Eo, 3 de decembro de 1932.

${ }^{30}$ Nesta ocasión fíxose coincidir a inauguración co día da morte de Miguel de Cervantes, e Sanz pronunciou unha conferencia acerca da evolución da vivenda desde os tempos primitivos (ibídem, 29 de abril de 1933).
} 
A nova da sublevación das tropas españolas no norte de África suscitou nel o comprensíbel desacougo, mais nun primeiro momento pensou, coma moitos outros, que o goberno lexítimo da República axiña se faría co control da situación. De modo que, malia ser período non lectivo, continuou dedicándose aos quefaceres profesionais, concretamente a planificar e preparar as clases do seguinte curso, en que tiña previsto aplicar unha metodoloxía que deixaría unha ampla marxe de autonomía ao alumnado, pois cada neno tería o seu propio proxecto e compromiso de aprendizaxe e progresaría ao seu ritmo, auxiliado polo mestre e por materiais diversos. Tamén traballaba, en compañía dun concelleiro e de dous mestres de obras, no proxecto de acondicionamento da aduana vella para que puidese acoller - mentres non houbese un edificio ad hoc- a escola graduada de doce seccións que se acababa de crear e ía modificar radicalmente o panorama escolar da vila, o que permitiría que se cumprise un dos seus máis persistentes soños. ${ }^{31} \mathrm{E}$ continuou elaborando informes para o xulgado como perito caligráfico, impartindo clases particulares aos netos de José Acevedo Martínez, do que ademais era secretario, e traballando na elaboración do novo regulamento da Sociedade de Beneficencia e Instrución «La Concordia» en compañía de Ramón Fernández de Soto, tal como lles fora encomendado pola comisión designada para estes efectos pola devandita sociedade..$^{32}$ Mais consonte transcorrían as horas e chegaban noticias do que acontecía en Galicia e noutras latitudes, a inquedanza íase agrandando e a xente estaba cada vez máis atenta ao que anunciaban as radios, nomeadamente aquelas que sintonizaban co credo político de cadaquén.

Os sectores republicanos máis combativos da vila, que controlaban a alcaldía, constituíron un comité co propósito de organizaren a resistencia aos sublevados, para o que adoptaron diversas medidas, entre elas a requisa dalgunhas armas. A resistencia foi vencida, e no curso do desigual enfrontamento produciuse a morte de seis resistentes e dunha muller que observaba os acontecementos. As persoas consideradas desafectas, entre elas o noso home, foron detidas e ingresadas no cárcere, que rexistrou 74 ingresos só 024 de xullo. Outras morreron como consecuencia do proceso represivo que se desencadeou nos días sucesivos. O seu número, segundo cálculos de Xabier Buxeiro Alonso, a quen seguimos neste reconto, ascendeu a 22, sumando «paseados" e «executados». ${ }^{33}$

A detención de Sanz tamén se produciu o 24, cando estaba traballando na escola e se presentou un militar coa orde de conducilo até o cárcere da localidade. Nela foi interrogado e maltratado polo tenente da Garda Civil Antonio Aranguren Ponte, fillo, por certo, do xeneral do mesmo corpo cuxa actuación resultará fundamental para facer fracasar a

\footnotetext{
${ }_{31}$ O subsecretario do Ministerio de Traballo, José López Varela, comprometérase a crear o grupo escolar nunha reunión que tivo con varios representantes de Ribadeo a comezos de 1936 (ibídem, 25 de xaneiro de 1936). ${ }^{32}$ Algunhas destas actividades están recollidas nas memorias do protagonista desta historia, e outras na documentación examinada para realizar a nosa investigación. José María Lombardero Rico ocupouse da historia de La Concordia en Sociedade Ribadense, pp. 37-50, e rexistra a presenza de Sanz en cargos directivos.

${ }^{33}$ Xabier Buxeiro Alonso, "Os verdugos e a sociedade. A violencia sublevada en Ribadeo (1936-1941)", en Golpistas e verdugos de 1936. Historia dun pasado incómodo, ed. Lourenzo Fernández Prieto e Antonio Míguez Macho (Vigo: Galaxia, 2018), 184-199.Véxase tamén Carlos F. Velasco Souto, 1936. Represión e alzamento militar en Galiza (Vigo: Edicións A Nosa Terra, 2006), nomeadamente as páxinas 292-294.
} 
sublevación en Cataluña. ${ }^{34}$ Ao día seguinte levárono, en unión doutros detidos, a Lugo, onde chegaron ás tres da madrugada do día 26, logo de permaneceren depositados varias horas no cárcere de Mondoñedo. Durante o seu traxecto, os presos foron insultados por algunhas persoas, que os cualificaban de traidores, asasinos ou roxos. Como o cárcere estaba desbordado, foron parar aos baixos do edifico que ocupaba Radio Lugo, a carón da casa consistorial. A mediados de decembro de 1936 pasou ao edificio da prisión provincial, e ao cabo duns tres meses foi enviado a Mondoñedo debido á falta de espazo.

\section{Expediente de depuración}

Na prisión de Mondoñedo estaba cando se lle comunicou oficialmente que fora destituído da súa escola. Non o sorprendeu a noticia, pois xa lle negaran o pagamento do soldo correspondente ao mes de xullo. O que o intrigou foron as palabras finais que lle trasladaba o oficio: "Lo que me complazco en comunicar a Vd. a los efectos consiguientes.»35 $\mathrm{Cal}$ sería o significado que se debía atribuír a tal compracencia?

A orde de destitución estaba asinada o 5 de setembro de 1936 polo gobernador civil de Lugo, Ramón Bermúdez de Castro, e fora publicada dous días despois no boletín oficial provincial. Acompañábano Pedro Pareja Morales (Páramo) e Jesús Pereira Vilares (Ansareo-Neira de Xusá), que recibiron idéntico castigo. ${ }^{36}$ No conxunto da provincia foron sancionados pola autoridade gobernativa durante os primeiros meses da guerra, e antes de se constituíren as comisións depuradoras, 151 mestres e 35 mestras, segundo cómputos realizados por María Jesús Souto Blanco. ${ }^{37}$ Agás dúas sancións correspondentes a novembro, o resto foron ditadas en agosto e setembro, e o partido xudicial con máis casos resultou ser 0 de Ribadeo, onde ascenderon a 22, malia ser o que reunía un menor número de habitantes: 23490 en 1930, fronte aos 81973 de Lugo, con 20 sancionados, ou os 57261 de Chantada, con $19 .{ }^{38}$

A súa depuración foi realizada pola Comisión C, encargada do profesorado dos institutos, por exercer daquela na escola preparatoria do Instituto de Ribadeo. Na súa condición de mestre corresponderíalle, no entanto, a Comisión $\mathrm{D}$, encargada da depuración do maxisterio. ${ }^{39}$ De feito, o primeiro documento que lle chegou a aquela foille remitido por

\footnotetext{
${ }^{34}$ Unha recreación literaria dos feitos protagonizados por José Aranguren Roldán pode lerse en Lorenzo Silva, Recordarán tu nombre (Barcelona: Destino, 2017).

${ }^{35}$ Uno de tantos, 39.

${ }^{36}$ Expediente de depuración, Arquivo Xeral da Administración (Alcalá de Henares), 32/13320-101, do que procede a documentación citada neste apartado.

${ }^{37}$ María Jesús Souto Blanco, La represión franquista en la provincia de Lugo (1936-1940) (Sada: Edicións do Castro, 1998), 311.

${ }^{38}$ Rodrigo Alvarado Iglesias, «A primeira etapa do proceso de depuración de mestres e mestras de primeiro ensino na provincia de Lugo: agosto-novembro de 1936", Sarmiento. Anuario Galego de Historia da Educación, no. 18-19 (2015): 111-128. O número de habitantes está tirado de Narciso de Gabriel, Ler e escribir en Galicia. A alfabetización dos galegos e das galegas nos séculos XIX e XX (A Coruña: Servizo de Publicacións da Universidade da Coruña, 2006), 336.

${ }^{39}$ Sobre o proceso de depuración do maxisterio en Galicia pode consultarse o monográfico publicado en Sarmiento. Revista Galego-Portuguesa de Historia da Educación, no. 21 (2017): 9-158 e 203-237.
} 
esta. Tratábase dun informe sobre varios mestres da bisbarra de Ribadeo asinado na Devesa por José Acevedo 02 de setembro de 1936. A Sanz acusábao de facer propaganda socialista, pública e privada, antes e despois das eleccións, dentro e fóra do municipio, en compañía polo regular dos irmáns Pérez Prieto, o médico e o farmacéutico, así como de César Margolles de la Vega e outros mestres. Estaba casado canonicamente e tiña dous fillos, un deles sen bautizar. «En la escuela no sé que haya enseñado doctrinas disolventes, y por sus condiciones personales, ejerce verdadera jefatura sobre sus discípulos y compañeros de magisterio».

A Comisión C, constituída 01 de decembro de 1936, estaba presidida polo gobernador civil, o seu secretario era Delio Mendaña Álvarez, catedrático do Instituto de Lugo, e os restantes membros Manuel Sureda, arquitecto do Catastro, Juan Bautista Varela Fernández, enxeñeiro da Deputación, e María Padrón, profesora da Normal. En sesión que tivo lugar 029 de decembro, leuse o informe do arcipreste-párroco de Ribadeo sobre o profesorado do instituto desta localidade, que coincidía co que posuía o presidente da Comisión, e que, polo menos no tocante á persoa que nos ocupa, foi trasladado na súa literalidade, e sen ningún tipo de matización, ao prego oficial de cargos. Este foi remitido á Garda Civil de Ribadeo para que llo entregase ao interesado, e a Benemérita devolveuno coa advertencia de que Sanz se atopaba na prisión lucense, así que a ela lle foi reenviado.

O 9 de xaneiro de 1937 o mestre manifestou o seguinte verbo dos cargos que se lle apuñan:

Al 1ํ: «Ser de ideología socialista» - Que jamás pertenecí a ninguna Agrupación ni Sociedad de tal carácter.

Al 2ํ: «Haber hecho propaganda en mítines del Frente popular» - Ser cierta mi intervención en algunos actos públicos, dedicándome principalmente a la defensa de la Escuela nacional, exhortando a los padres para que enviasen constantemente sus hijos a la Escuela a fin de que pudieran capacitarse para ser ciudadanos útiles a la Patria y, sobre todo, laborando para la supresión de lo que consideré siempre como una vergüenza para Ribadeo: el que haya solamente una Escuela nacional de niñas y dos de niños en una población de más de tres mil habitantes.

Al 3ㅇ: «Ser elemento destacado del Frente popular de Ribadeo» - Que no he pertenecido a ningún partido político y, por consiguiente, no puedo ser elemento destacado en una entidad de la que ni siquiera formo parte.

Al 4ㅇ: «No ser católico» - Como puede certificar el Sr. Cura párroco de Ribadeo, estoy casado canónicamente, y mis dos únicos hijos se hallan bautizados en la Iglesia parroquial de Ribadeo. Además, en mi actuación pública he propagado y defendido, siempre, uno de los principios fundamentales de la Religión católica: «No desees para otro lo que no quieras para ti», terminando algunas de mis intervenciones con las célebres palabras de Jesucristo: «Amaos los unos a los otros».

Como pode apreciarse, os cargos son breves e contundentes, e recollen as dúas dimensións que concentraron os esforzos do proceso depurador: frontepopulismo e laicismo. As respostas tamén son breves e están perfectamente calibradas. Non nega sustentar unha ideoloxía de orientación socialista, e limítase a afirmar que non pertencera a ningunha entidade de tal carácter. Tampouco nega a participación en mitins da Fronte Popular, pero matiza que as súas intervencións sempre estiveran encamiñadas á defensa 
da escola nacional. E dado que esta fronte estaba formada por partidos, e el non militara en ningún, mal podía ser un dos seus elementos máis destacados. Finalmente, fronte á acusación de non ser católico, apela ao seu matrimonio relixioso e ao bautizo dos seus fillos, e tamén afirma compartir algunhas das máximas da doutrina católica.

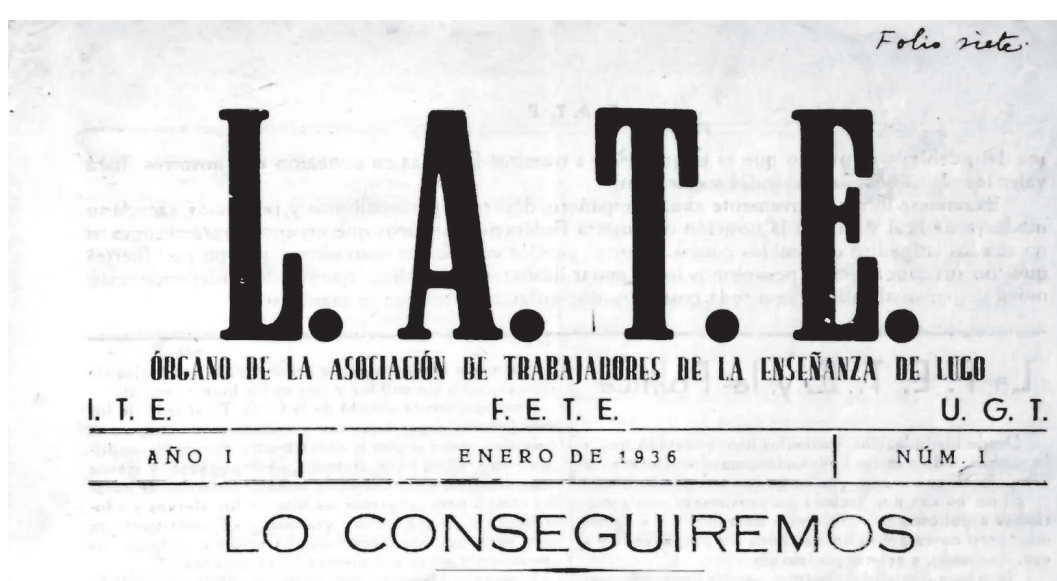

Por primera vez nos acercamos a los Maestros para que conozcan, no la propaganda que unos cuantos aprovechados hacen de nosotros, sino la verdad, la orientación que sale de nuestros cuadros, nuestro programa, la visión clara y decidida que nuestra Federación tiene de los problemas del Magisterio y la solución que hemos de darle.

Convencidos que de la "Gaceta» no se puede esperar la menor de cuantas reivindicaciones anhela nuestra clase, nos hemos de preparar a conquistarlas, a merecerlas y exigirlas; vemos que nuestros problemas no son de tipo personal, ni personalmente podrá alguien daries cima; se precisa la acción colectiva sin desfallecimientos ni partidismos; la acción decidida de todo el Magisterio, y ese será nuestra objetivo.

Un Magisterio estático, tradicional, anquilosado y retrógrado ha de perecer ahogado, intoxicado en su mismo ambiente. El Magisterio, por naturaleza, ha de ir recobrando sus medios, sus concepciones. Vivir o morir. Permanecer aislado en si mismo es firmar la sentencia del Maestro y la Escuela. Caminar hacia adelante poseidos de un fuerte y decisivo optimismo debe ser norma vital de todo compañero, secundar métodos y medios, romper trabas que impiden el libre desarrollo, dejar que la fuerza viva ascensional de una sociedad que se rehace con nuevos elementos imprima una

Maestro, si tienes verdadero entusiasmo, vocación e interés por renovar tus medios y conseguir la consideración a que tienes derecho, ingresa en los Trabajadores de la Enseñanza

marcha acelerada a la evolución, siendo nosotros el instrumento de liberación humana por donde lleguen a zancadas normas sociales de equidad y justicia sin odios ni prejuicios, sin asperezas nefandas, sin despotismos; todo fraternidad, solidaridad, espíritu democrático, comprensión y justo aprecio del «valor» social.

Es vergonzante que, aprisionados por personalismos y otros ismos más ridiculos y con menos contenido, nos enfrentemos los compañeros haciéndole el juego a unos pocos vividores, que explotan la situación de inferioridad en su provecho. Naúa de claudicaciones, por nuestra misión debemos tener una personalidad definida. A ella hemos de encomendar la defensa de nuestras posisiones. Cuando se nos desvía ds los problemas fundamentales entreteniéndonos con zarandajas que solo aprovecha a unos pocos, rompamos las ligaduras que nos atan a problemas de tipo individual leṿantando nuestro espíritu hacia la meta común, donde encontraremos resueltas de una vez todas esas dificultades mezquinas. No suplicar. Es contrario al espíritu que tenemos la obligación de sembrar. Pedir, exigir valientemente, con espíritu de hombres que cumplen con un deber y hacen valer un derecho. Esos son los hombres de Trabajadores de la Enseñanza, que aspiramos sea la de una gran mayoría de los Maestros Españoles.

El Magisterio puesto en pié, siguiendo una ruta marcada dignificada, sî́ humillaciones, encuadrado en las filas de nuestra Federación, buscando amplios horizontes tanto en el campo pedagógico como en el sindical, será pronto el exponente sincero y exacto de una cultura que llegue al al-

Todo camarada debe cuidarse de la difusión de nuestra propaganda, siendo él vehículo para que llegue al más aparłado compañero

Primeiro número da revista L.A.T.E. 
Sobre a escola nacional publicárase un artigo no primeiro número da revista L.A.T.E. Órgano de la Asociación de Trabajadores de la Enseñanza de Lugo, datado o 1 de xaneiro de 1936. Estaba asinado por un tal Sanz, titulábase «Por la Escuela nacional», denunciaba os ataques de que esta era obxecto e facía un chamamento á súa defensa por parte do maxisterio. Alguén fornecera un exemplar deste número aos encargados da depuración, que identificaron a Gregorio Sanz García como o autor do artigo. Resultaría difícil diferenciar un cargo neste texto. A gravidade radicaba, en todo caso, na súa publicación nun órgano da FETE, xa que a militancia nesta federación sindical era un dos cargos máis recorrentes nos expedientes de depuración. ${ }^{40}$

Debido á resposta dada ao terceiro cargo —-militancia na Fronte Popular-, a Comisión decidiu preguntar ao director da prisión provincial polas circunstancias do detido. Ao comprobar que era un detido gobernativo de guerra, oficiouse ao gobernador militar para que clarificase a relación que tivera co movemento frontepopulista. A máxima autoridade militar da provincia foi moi precisa no informe que redactou o 27 de xaneiro de 1937: 0 agora preso fora vogal da Federación de Traballadores do Ensino, socialista e destacado propagandista da Fronte Popular: «La opinión pública le achaca ser uno de los que mayores éxitos alcanzaba en la propagación de ideas marxistas. Individuo voluble, perteneció a la política de la Dictadura Militar, siendo favorecido por ella.» A razón de acadar tales éxitos radicaba no don da elocuencia que posuía, como se reiterará en moitos dos informes que sobre el se redactaron. Unha calidade que, ben encamiñada, podía ser virtuosa, pero que se convertía en perversa cando se puña ao servizo do mal.

Catro días antes de se redactar o anterior escrito, a Comisión $\mathrm{C}$ rexistra a recepción doutro informe sobre o mestre remitido pola D, presidida por Alfredo Rodríguez Labajo, director do Instituto, e da que era secretario Joaquín García Ojeda, inspector xefe de ensino primario. Estaba asinado polo alcalde de Ribadeo o 25 de agosto de 1937 e dirixido ao reitor da Universidade de Santiago. Antonio Moreda Martínez, nomeado dous días antes polos sublevados presidente da Comisión Xestora, ${ }^{41}$ caracterizaba a persoa que nos ocupa como extremista e propagandista da Fronte Popular, aínda que a opinión que persoalmente lle merecía non pode dicirse que fose mala:

\begin{abstract}
Lo considero culto, inteligente y trabajador en la Escuela; no creo que en esta haya hecho propaganda política. Considero que se trata de persona de corazón y amor al niño; envenenado por lecturas marxistas y convencido por ellas, llegó a esas propagandas socialistas, quizá comunistas, pero en el bien entendido [de] que a juicio del informante, dicho maestro es de tipo evolutivo y por tanto enemigo de toda violencia, de todo acto de fuerza, y seguramente, si tuvo conocimiento -cosa que ignora el que informa- de la magnitud y de los procedimientos a seguir por los marxistas en el movimiento que preparaban, tuvo que sufrir desengaños y torturas sin cuento.
\end{abstract}

\footnotetext{
${ }^{40}$ Nas súas memorias non nega, como veremos, a pertenza a Traballadores do Ensino, da que tamén quedou constancia na prensa da época. No congreso provincial de L.A.T.E., organizado en Lugo no mes de abril de 1936, foi un dos encargados de pronunciar os discursos de clausura. Nesta reunión elixíronse os relatores para o próximo congreso da Federación Galega en Vigo (El Progreso, 11 de abril de 1936).

${ }^{41}$ Buxeiro Alonso, "Os verdugos e a sociedade», 186.
} 
Sen reparar nestas últimas palabras, e centrándose nas subscritas por José Acevedo e polo gobernador militar, a Comisión acordou propor a terceira das sancións estipuladas na circular de 7 de decembro e 1936, é dicir, a separación definitiva do ensino. ${ }^{42}$ Así se fixo mediante unha orde ministerial ditada o 17 de marzo de 1937.

En 1958, cando xa levaba 21 anos afastado do ensino público — como imos ver, durante este tempo traballará na escola privada-, solicitará ser readmitido no maxisterio, 0 mesmo que fixeron outros moitos compañeiros de profesión sancionados polo franquismo. A solicitude ía acompañada de dezaseis informes, asinados catro deles en 1950, 1954 e 1955 e os doce restantes en 1958. O cualificativo que máis se repite para caracterizar a súa conduta e a súa actuación como profesor particular na cidade de Lugo durante as décadas de 1940 e 1950 é o de «excelente», e nesta apreciación coincidían individuos de moi diversa condición. Entre eles Enrique Otero Aenlle, gobernador civil de Lugo, José Santín Carballo, cura párroco de Santiago (Lugo), e Antonio Carvajal Herbón, director de Radio Lugo, emisora coa que colaborara nos últimos quince anos, imprimindo ás súas intervencións «un elevado espíritu de patriotismo y el más acendrado sentimiento cristiano". Algúns dos que o avalaban escollérano para educar os seus fillos, como foi o caso de Francisco Alonso Rey, notario; Purificación de Cora Sabater, director do xornal El Progreso; Víctor Basanta López, vicepresidente da Deputación Provincial; e Eduardo Urgorri Casado, que emitiu dous informes, un na súa condición de subxefe provincial da Falanxe e outro como subxefe do Movemento. Neste último faise constar a súa pertenza ao Servizo Español do Maxisterio, circunstancia que tamén acredita Manuel Taboada Salgado, delegado provincial de Educación, segundo o cal exercía a xefatura na sección de Ensino Privado desta organización, cargo que desempeñaba a plena satisfacción das autoridades.

Luís Varela García, director do Colexio Balmes de Lugo, onde traballara como mestre entre 1945 e 1949, subliñaba que o entusiasmo pola docencia, unido ás notábeis dotes pedagóxicas, lle permitiran gañarse o agarimo dos nenos, o respecto das familias e a estima dos compañeiros. Luciano Fernández Penedo, director da Escola de Comercio, afirmaba que exercía o ensino particular "con eficacia [...] y éxito poco comunes», e así o evidenciaban os "extraordinarios» resultados dos seus alumnos nos exames de ingreso neste centro. Idéntica observación facía Daniel Sarandeses, cóengo da catedral e profesor de Relixión no Instituto Feminino de Lugo, sobre as alumnas preparadas por Sanz para acceder ao ensino secundario, ao tempo que manifestaba o seu «respeto, afecto y hasta admiración» polo labor que viña facendo, que nalgúns casos seguira moi de preto. Lázaro Montero de la Puente, catedrático e director do Instituto Masculino de Lugo, era aínda máis contundente no seu informe:

\footnotetext{
${ }^{42}$ A circular da Comisión de Cultura e Ensino dirixida aos vogais das comisións depuradoras de instrución pública prescribía a "separación definitiva del servicio para todos los que hayan militado en los partidos del «Frente Popular» o Sociedades secretas, muy especialmente con posterioridad a la revolución de Octubre, y de un modo general, los que perteneciendo o no a esas agrupaciones hayan simpatizado con ellas u orientado su enseñanza o actuación profesional en el mismo sentido disolvente que las informa" (Boletín Oficial. Provincia de La Coruña, 15 de decembro de 1936).
} 
Que conozco y trato personal y profesionalmente a D. Gregorio Sanz García desde hace catorce años. Que desde esa fecha viene distinguiéndose por sus especiales dotes pedagógicas que hicieron de su escuela particular la preferida de la ciudad, pudiendo testificar el que certifica como examinador durante muchos años de Ingreso en este Instituto, que siempre se distinguieron [los] en ella preparados, tanto por su información como por su educación, cosa que puede afirmar aun como particular por haber tenido en ella a sus hijos.

Tampouco faltaron informes de Ribadeo, cuxo alcalde, Francisco Maseda García, deixaba constancia, certamente, da propaganda esquerdista que realizara nos tempos da República, mais tamén da súa condición de home bo, pacífico e traballador, circunstancias que o fixeran merecedor do recoñecemento dos seus concidadáns. 0 arcipreste-párroco da vila tamén informou en termos favorábeis.

Finalmente, o inspector xefe de Ensino Primario, Joaquín García Ojeda, avalou de forma incondicional a súa traxectoria profesional, tanto na escola nacional republicana como na escola privada franquista. Antes de ser afastado do ensino estaba «considerado como uno de los Maestros más destacados profesionalmente de la provincia, por su gran preparación pedagógica y por su entrega absoluta a la misión docente que se le había confiado, sin que a ella llevase, en ningún momento, ideas disolventes ni perturbadoras, conducta concordante con su catolicidad práctica.» E desde 1942 exercera como mestre particular na capital provincial, o que puña de manifesto a súa vocación polo ensino, «gozando de gran prestigio profesional y habiéndose captado el afecto y consideración de todas las clases sociales no solo por aquel merecido prestigio, sino también por sus dotes personales, juzgándole como sinceramente adepto a los postulados del Nuevo Estado.» Nada menos.

O Xulgado Superior de Revisións, atendendo á relevancia dos testemuños que se achegaban, e mesmo ao consignado nalgúns dos informes que serviran de fundamento para a súa separación do ensino, tendo en conta tamén que non fora sometido a expediente de responsabilidades políticas nin a causa militar, así como os 21 anos de castigo sufridos, acordou readmitilo coa sanción de traslado durante tres anos fóra da provincia e inhabilitación para o desempeño de cargos directivos e de confianza, proposta que foi aceptada polas autoridades ministeriais.

Sorprende que na resolución se afirme que non estivera sometido a un proceso xudicial de carácter militar, o que, como veremos deseguido, non era certo. Mais ningún informante aludiu a este feito, e ninguén fixo tampouco indagacións ao respecto. ${ }^{43}$ É posíbel que isto teña algunha relación cunha nota escrita a máquina, sen sinatura, dirixida a Antonio Tena Artigas, secretario xeral técnico do Ministerio de Educación, e redactada seguramente por algún responsábel do Xulgado de Revisións. Nela facíase saber que se examinara a solicitude de readmisión do mestre "por quien tan vivamente se interesaba», e que se remitira á Dirección de Ensino Primario informada de forma favorábel. Este tipo de intercesións, polo que estou a constatar nas miñas pescudas sobre o proceso de depuración do profesorado, adoitaban ser bastante frecuentes.

${ }^{43}$ Tamén se lle abriu un expediente de responsabilidades políticas, en virtude do cal foi sancionado cunha multa de dez mil pesetas que non pagou por falta de recursos (Uno de tantos, 140-141). 


\section{Consello de guerra}

Cando Gregorio Sanz estaba preso en Mondoñedo, o gobernador militar de Lugo, coronel Óscar Nevado de Bouza, visitou o cárcere desta localidade e falou con algúns dos presos. A un deles preguntoulle se era comunista, ao que este contestou: «Non señor, eu sonlle ferreiro». Ao mestre atopouno detrás da mesa que lle servía para exercer o seu oficio de "ordenanza» ${ }^{44}$ e interesouse pola súa profesión, segundo el mesmo nos conta:

- Maestro Nacional -le contesté. Dio un paso atrás y dijo:

-Y pertenecería a esa gloriosa (con retintín) asociación titulada Trabajadores de la Enseñanza?

- Sí, señor -respondí.

- Y Vd. en vez de enseñar a sus alumnos a levantar amorosamente el corazón a Dios les enseñaría a levantar airadamente el puño cerrado?

- De mi actuación como Maestro - repliqué- le puede informar a Vd su Ayudante-Secretario, aquí presente, que me conoce hace tiempo. Y ante los signos de afirmación de este, dijo:

- Bien, bien, ya iremos viendo estas cosas. Y siguió su visita sin más incidentes. ${ }^{45}$

Pois ben, o coronel semella que saíu do cárcere con ganas esculcar o comportamento dun preso que non se deixara intimidar polo seu uniforme nin polo seu cargo, e seguramente revisou ou encomendou a alguén que revisase o expediente gobernativo que se lle estaba a instruír. Ao advertir "cargos de tipo delictivo» nos informes elaborados pola alcaldía, a Garda Civil e a Falanxe, ${ }^{46}$ remitiunos a Rogelio Borondo Sánchez, capitán honorífico do Corpo Xurídico, para que procedese á formación da causa de depuración de responsabilidades, e asemade facíalle saber que o mestre se atopaba por aquelas datas en Mondoñedo. Este oficio, datado o 31 de outubro de 1937, é o que abre o sumario do consello de guerra a que será sometido Gregorio Sanz. ${ }^{47}$ Cando se arquivou a causa, 01 de maio de 1942, sumaba 125 folios útiles e correlativamente numerados. ${ }^{48}$

\footnotetext{
${ }^{44} \mathrm{O}$ mestre fora escollido para organizar a alimentación dos reclusos e despachar as cuestións de carácter administrativo do cárcere.

${ }^{45}$ Uno de tantos, 59-60.

${ }^{46} \mathrm{O}$ informe da Garda Civil estaba asinado polo brigada Pablo de la Puente Aguirre que, como veremos, terá un importante protagonismo nesta causa. Ao igual que outros informantes, aludía á participación de Sanz en todos os mitins de esquerda que se produciran en Ribadeo, Vilaodriz, Foz, Barreiros e outros lugares: «dada su facilidad de palabra se le consideraba como el imprescindible para dichos actos."

${ }^{47}$ Sobre a mecánica e o significado dos consellos de guerra como mecanismo de represión véxase Julio Prada Rodríguez, La España masacrada. La represión franquista de guerra y posguerra (Madrid: Alianza Editorial, 2010), 163-215. Na páxina 182 podemos ler: «Discrecionalidad, libre apreciación y extenso arbitrio permitieron a los consejos de guerra condenar o exculpar a su antojo a decenas de miles de personas a las que nunca se reconocieron las más elementales garantías judiciales propias de un Estado de Derecho, quedando expuestas al crédito que sus integrantes quisiesen otorgar a las denuncias, informes y testimonios que pesaban contra ellos.» Unha visión sintética do terror practicado polo fascismo español pode lerse en Paul Preston, El holocausto español. Odio y exterminio en la Guerra Civil y después (Barcelona: Debate, 2011).

${ }^{48} \mathrm{~A}$ non ser que se especifique outra procedencia, as fontes que sustentan este apartado proceden desta causa militar, á que se fai referencia na nota 3.
} 
O xuíz ordenou que o preso fose trasladado ao cárcere de Lugo, onde se ía instruír a causa, e nela ingresou 05 de novembro. Asignóuselle unha cela que, malia ser individual, xa estaba ocupada por once reclusos. As condicións da prisión provincial eran peores que as ofrecidas pola do partido xudicial, o mesmo en materia alimenticia que no tocante ao ar que se respiraba, tanto en sentido literal coma figurado.

Ao día seguinte prestou a primeira declaración, centrada en matizar o alcance dos dous cargos arredor dos cales se vertebrará a causa: propaganda esquerdista e participación na organización da resistencia de Ribadeo ás forzas sublevadas. Estas foron as súas palabras:

Que no es verdad que haya hecho propaganda netamente marxista ni que interviniese en mítines de esa naturaleza, y lo único que ha hecho fue, con motivo de las elecciones de Febrero del 36, y en toda ocasión que ha tenido, procurar defender la escuela Nacional exhortando a los padres de familia a que enviasen sus hijos a la escuela, como medio de llegar a ser buenos ciudadanos; y de manera especial para conseguir la creación de escuelas nacionales en Ribadeo por no existir en esta Villa más que una de niñas y dos de niños. Para defender esta misma cuestión intervino en un acto celebrado el día 1ํ de Mayo. Que con motivo de aquellas elecciones hizo propaganda de defensa del ideario de izquierdas en lo que se refiere a la enseñanza, especialmente en los relacionado con el artº 48 de la Constitución. ${ }^{49}$ Que solo en Barreiros hizo la propaganda que deja indicada, y en Villaodriz y en Villameá no hizo propaganda de ninguna clase. Que no es verdad que estuviera con elementos rojos, reunido en el Ayuntamiento, los días que aquellos dominaron en la villa, ni tampoco anduvo con los cabecillas en ningún momento, al menos en plan de tomar acuerdos o medidas, lo mismo antes que después del Movimiento. ${ }^{50}$

O certo é que o mestre tivera un importante protagonismo na vida política ribadense nos tempos da República. Sabemos que nas eleccións de 1931 participou nun mitin agrario e noutro da conxunción republicano-socialista realizados en Ove e en dous desta última coalición organizados en Rinlo e na Ponte de Arante, ${ }^{51}$ acompañado neste caso de César Margolles, tamén mestre. Nas de 1936 foi un dos oradores no «mitin antifascista» que tivo

\footnotetext{
${ }^{49}$ Este artigo comezaba afirmando que «el servicio de la cultura es atribución esencial del Estado, y lo prestará mediante instituciones educativas enlazadas por el principio de la escuela unificada", e continuaba comprometéndose, entre outros principios, coa gratuidade e a obrigatoriedade do ensino primario e cunha educación inspirada nos ideais do laicismo, 0 activismo metodolóxico e a solidariedade humana. Véxase Historia de la Educación en España. IV La educación durante la Segunda República y la Guerra Civil (1931-1939) (Madrid: Ministerio de Educación y Ciencia, 1991), estudo preliminar a cargo de Antonio Molero Pintado.

${ }^{50}$ A declaración foi máis extensa, especialmente no tocante á escola, como precisa o mestre nas súas memorias, nas que podemos ler: «Declaré ser cierta mi participación en varios mítines de los llamados de izquierdas, porque era Maestro Nacional, porque soñaba con una Escuela digna, iniciadora de cultura, sembradora de nobles ideales, cultivadora de espíritus abnegados, capaz de fundamentar sólidamente una España próspera y pujante en el porvenir; y hasta entonces solamente los partidos de izquierdas habían incluido en sus programas aspiraciones y proyectos afines a los sueños que sobre el futuro de la Escuela yo me había forjado.» Unha escola onde convivisen ricos e pobres e primase o mérito. Preguntado por que criticaba a escola privada, manifestou que o facía debido a que "era fomentadora de la lucha de clases", por ser patrimonio dos sectores acomodados, que consideraban «una deshonra el asistir a la Escuela pública, como despectivamente llamaban a la Escuela Nacional.» E cando a escola privada se vía obrigada a admitir algúns nenos ou nenas de forma gratuíta, por mor das subvencións que recibía, aplicaba un trato diferente a ricos e pobres, e nalgúns casos mesmo lles asignaba portas específicas: os primeiros entraban pola principal e os segundos pola traseira (Uno de tantos, 71-72).

${ }^{51}$ Las Riberas del Eo, 16, 23 e 30 de maio de 1931.
} 
lugar en Vilaframil, no mitin electoral da Unión de Esquerdas de Ribadeo en Remourelle (Arante) $)^{52}$ e nun mitin social-galeguista en Ribadeo, en que actuou el en representación do socialismo e Manuel Prieto por parte do galeguismo. ${ }^{53}$

A súa presenza como orador nos actos organizados para celebrar o Primeiro de Maio tamén tivo continuidade: en 1932 dirixiuse a un auditorio formado por «los trabajadores ribadenses y muchos campesinos», 54 ao ano seguinte falou en nome da Sociedade Obreira «La Prosperidad», de carácter socialista, ${ }^{55}$ acompañando a José Novo, que representaba a Agrupación Socialista; ${ }^{56}$ en 1934, ademais de intervir na Casa do Pobo, onde abundaban as pancartas antifascistas, fixo unha loa de Pablo Iglesias na praza que se lle dedicou, onde se instalou unha lápida; ${ }^{57}$ finalmente, en 1936 compartiu tribuna con César Margolles, que disertou sobre o socialismo, e Selina Asenjo, unha representante asturiana das Xuventudes Socialistas, que centrou o seu discurso na revolución asturiana de outubro. Neste último ano, Sanz, nun «elocuente discurso»-aínda que a elocuencia non constituía novidade-, denunciou o abandono do ensino público en Ribadeo e o esforzo do maxisterio para que nenos e nenas recibisen «la educación y los conocimientos necesarios para luchar con éxito por la vida», mais tamén denunciou a "covachuela inmunda" en que vivían moitos traballadores e apelou ao cooperativismo para solucionar esta situación. ${ }^{58}$

É moi verosímil que tanto nos mitins electorais coma nos actos do Primeiro de Maio e noutros escenarios centrase as súas intervencións arredor da escola nacional. Sirva como exemplo unha conferencia que pronunciou no Pósito de Rinlo en 1932, na que explicou as novidades que introducía a constitución republicana neste ámbito, censurou os pais que non enviaban os seus fillos ás escolas, soñou coa escola do futuro e rematou solicitando aos mariñeiros a creación dunha biblioteca infantil, outra das súas angueiras. ${ }^{59}$ Ao ano seguinte interveu no mesmo escenario José Novo, presidente do Comité Socialista de Ribadeo, e deseguido, "a petición de varios admiradores", falou Sanz, que declarou proceder dunha familia católica e respectuosa coa tradición, confesou que tomara conciencia das inxustizas cando estivera en Córdoba e tivera a oportunidade de comprobar a miseria dos xornaleiros andaluces, afirmou que a ignorancia propiciaba a opresión e díxolles aos

\footnotetext{
${ }^{52}$ Ibídem, 11 de xaneiro e 8 de febreiro de 1936.

${ }^{53}$ La Voz de Galicia, 21 de xaneiro de 1936.

${ }^{54}$ Las Riberas del Eo, 7 de maio de 1932.

${ }^{55}$ Lombardero, Sociedade Ribadense, 15-36.

${ }^{56}$ Las Riberas del Eo anunciaba os actos 029 de abril de 1933.

57 Ibídem, 5 de maio 1934.

${ }^{58}$ Ibídem, 2 de maio de 1936. José María Lombardero Rico afirma que os oradores locais máis asiduos nos mitins do Primeiro de Maio foron Manuel González Barcia, Antonio García Fernández e Gregorio Sanz García, e que os temas máis recorrentes eran «a carestía das subsistencias, que hoxe chamaríamos a cesta da compra; a denuncia da guerra colonial de Marrocos; a necesidade de vivendas para os obreiros e a dignificación do ensino público" (Sociedade Ribadense, 23-24). Segundo este autor, Sanz iniciaríase como orador en 1922, o ano mesmo en que chegou a Galicia, nunha concentración convocada polo Ateneo para protestar contra a represión dos estudantes madrileños por parte da policía e a morte de tres labregos en Guillarei (Tui) a mans da Garda Civil (ibídem, 68-69).

${ }^{59}$ Céltiga, 25 de abril de 1932.
} 
oíntes, que o seguían «con insuperable atención», que «los de arriba amedrentaban al pueblo con la palabra comunismo y que caso de triunfar este los trabajadores nada tenían que temer. ${ }^{60}$ Porque, como é ben sabido, resulta difícil falar da escola sen aludir ao contexto en que se inscribe.

Retomando a declaración prestada no cárcere de Lugo, que cuestionaba especialmente o afirmado pola alcaldía no seu informe, o mestre propuña que as súas palabras fosen confirmadas polos seguintes veciños: Saturnino Simal Santiago, industrial; Ramón Fernández de Soto y Fernández, avogado; Eduardo García Montalbán, consignatario de buques; Severino Cociña García, oficial de Correos; Antonio Cruzado Cora, director do Banco Herrero; e José Acevedo Martínez, propietario. ${ }^{61}$ Requirido polo instrutor da causa, o xuíz do partido xudicial de Ribadeo citounos a declarar o 10 de novembro, agás o último, que por estar enfermo prestou testemuño no seu propio domicilio tres días máis tarde.

Os catro primeiros cualificaron a conduta do investigado como «intachable», o quinto como «inmejorable, sin que se le pueda atribuir vicio alguno ni desdoro como persona», e o último como "excelente». Un verdadeiro señor, en suma, e tal é tamén a impresión que producen as súas palabras e o seu comportamento en quen isto escribe.

En relación coa súa actuación política durante a República, a primeira testemuña afirma que respondía a un esquerdismo moderado, "por no ser hombre de acción», mentres que as cinco restantes fan constar que participara en todos ou case todos os mitins de esquerda ou marxistas — «a los que ellos titulaban antifascistas», matizan algúns-, nomeadamente os organizados pola Fronte Popular, o que o convertía, en palabras de García Montalbán, no «mayor propagandista de esas ideas» e «en uno de los mayores envenenadores del campesino y del obrero".

Cinco testemuñas ignoraban se estivera presente na reunión celebrada no concello durante a noite do 22 ao 23 de xullo co propósito de organizar a resistencia á toma da vila polas tropas sublevadas, ${ }^{62}$ e García Montalbán exculpábao, en todo caso, de calquera responsabilidade na resistencia, pois

\begin{abstract}
no hay fundamento para indicar que directa o indirectamente tomase parte en los sucesos revolucionarios de esta Villa si bien horas antes de acordarse en el Ayuntamiento el alzarse en armas contra el Ejército dicho individuo estuvo reunido con los principales dirigentes del marxismo de Ribadeo en el propio Ayuntamiento. También le consta que el día veintitrés en que fue liberada la Villa por el Glorioso Ejército Nacional el citado Sanz no llevaba ningún signo externo que demostrase estar con los sublevados lo que sabe por haber estado con él aquella misma mañana después de estar ya el Ejército en la Plaza de España de la Villa.
\end{abstract}

\footnotetext{
${ }^{60}$ Las Riberas del Eo, 2 de decembro de 1933.

${ }^{61}$ É posíbel que se tratase do José Acevedo que en 1936 asinara o informe, xa citado, sobre varios mestres da bisbarra, aínda que a declaración que agora emite verbo de Sanz discrepa substancialmente da inicial.

${ }^{62}$ Foron varios os concellos nos que se constituíron Comités de Defensa da República para facer fronte ao golpe de estado, entre eles o de Ribadeo. Véxase Fernández Prieto e Míguez Macho (eds.), Golpistas e verdugos de 1936.
} 
Con posterioridade ao 18 de xullo, Fernández de Soto escoitáralle dicir que España necesitaba unha «república de orden», e a Cruzado Cora, que coincidiu con el 023 , cando se produciron os enfrontamentos armados na vila, pareceulle entender que se opuña á actuación das forzas de esquerda ou que, polo menos, condenaba a utilización de armas. 0 alcalde, pola súa banda, nun oficio datado o 20 de novembro, reiteraba ao xulgado militar que só lle constaba a actuación propagandista relatada en anteriores informes, e engadía: "Como se trata en mi sentir de un teorizante, enemigo de toda acción directa y violenta, no creo que haya tenido intervención en la resistencia que aquí se hizo al Ejército." Sabía, no entanto, que estivera na casa consistorial na noite do 22 de xullo, malia ignorar quen podería dar fe desta circunstancia, e tamén o 21, como podía informar o alférez da Garda Civil Pablo de la Puente Aguirre.

Ao xuíz instrutor designado inicialmente substituíuno o 16 de novembro, por orde do xefe da Oitava Rexión Militar, o capitán de Cabalaría Mariano Pérez Hickman e Hickman. A súa primeira decisión consistiu en solicitar ao xuíz de Ribadeo que tomase declaración precisamente a Pablo de la Puente.

O alférez corroborou que o mestre estivera efectivamente 021 nas dependencias do concello - mesmo tivera a oportunidade de falar con el一, e supuña que sería «para tratar cosas del Frente Popular», do que fora "gran propagandista». Descoñecía a súa actuación en relación co Movemento, e o concepto que lle merecía en materia moral, social e política era «malo». Aínda que as probas que se podían alegar na súa contra eran de "dominio público", xa que se lle pedían nomes de posíbeis testemuñas, citou os de Manuel de la Barrera Rodríguez (propietario), Leandro Torres Patiño (propietario), Manuel Vinjoy Reinante (médico) e os "camaradas» Luís Mira de Torres (estudante) e Gumersindo García Presno Martínez (avogado).

En relación coa conduta no mestre, nada lle aporán no dominio privado e moral as testemuñas propostas polo alférez, aínda que Torres e De la Barrera advertían que non se podía cualificar como bo cidadán a quen sostiña conviccións sociais e políticas alleas á «idea de orden». Os cinco corroboraron que interviñera en todos ou case todos os mitins frontepopulistas ou socialistas, e que fora un dos que máis se destacara «envenenando a la masa obrera en la que por esto y por su cultura ejerció una gran influencia» (De la Barrera), contribuíndo "a la rebeldía y a desarraigar todo amor Patrio" (García). Tres ignoraban se estivera no concello na noite do 22 de xullo, García afirmaba que o abandonara ás 11, e malia descoñecer o motivo de tal estadía «presume, dada la ideología política del Sanz García, que no haya sido otro que el de organizar o coadyuvar a la organización del movimiento revolucionario local», e De la Barrera declarou que, segundo rumores, abandonara a casa consistorial ás 12 .

Sobre este último extremo, Leandro Torres dixo que os máis indicados para informar eran os empregados do concello, polo que o xuíz de Ribadeo decidiu citar seis. Interrogados ao respecto, só un deles, José Antonio Lombardero Mon, varredor, vira entrar o mestre na casa do concello sobre as nove e media da noite. 0 resto dos citados ou ben non estiveran na casa consistorial, ou ben non viran o mestre, como foi o caso do garda municipal 
Agustín Martínez Tellado, que comezara a prestar servizo á unha da madrugada, e do sereno Jesús Gómez y Gómez, que entrara sobre a unha e media no despacho do alcalde, onde estaban reunidas varias persoas, mais non o mestre, e ninguén aludiu tampouco á súa presenza antes desa hora.

Unha vez realizadas as anteriores dilixencias, o xuíz instrutor redactou, con data do 6 de decembro de 1937, o auto co resumo dos feitos e as conclusións provisorias. 0 primeiro dos dous resultandos que o encabezan inscribía o proceso no marco legal estabelecido polo bando que declaraba o estado de guerra e derrogaba a legalidade republicana:

Que el día 18 de Julio de mil novecientos treinta y seis, en los territorios de soberanía del Norte de África se produjo un Alzamiento Nacional contra Gobiernos que devinieron ilegítimos al pretender someter a España a procesos de desmembración autonómica y soviéticos controles, Alzamiento secundado por gran número de guarniciones de la Península y que produjo la ruptura del orden jurídico entonces existente que fue sustituido por una nueva legalidad plasmada en los bandos declaratorios del Estado de Guerra, el cual fue proclamado en esta Provincia a las quince horas del día veinte del mismo mes y año.

O segundo resultando rexistraba a traxectoria esquerdista do mestre e a súa participación na resistencia organizada en Ribadeo para impedir a entrada na vila dun exército que decidirá arrogarse a representación de España facendo valer a forza das armas:

Que el paisano GREGORIO SANZ GARCÍA, Maestro Nacional de la Escuela preparatoria del Instituto de Ribadeo, correspondiendo a su marcada significación marxista como venía demostrando desde mucho antes del Glorioso Alzamiento, con su colaboración decidida en todos los actos denominados antifascistas que se celebraban en la comarca, colaboración valiosa para los fines perseguidos por el bloque antinacional denominado Frente Popular, dada su cultura, elocuencia y ascendiente, fue uno de los que más contribuyeron al efímero triunfo electoral de las izquierdas y posteriormente, ya proclamado el estado de guerra en toda la provincia, concurrió a una reunión con los cabecillas de la resistencia roja en la que parece se acordó oponerse a los patrióticos designios del Ejército Nacional con las armas en la mano, secundando con ello el plan general de resistencia que se hizo en otras regiones con organización y mandos militares, sin que esto prejuzgue la resultancia final del proceso.

Se neste contexto histórico houbese lugar para sorprenderse da arbitrariedade, sorprendería a contundencia coa que Hickman atribuía a Sanz a participación no movemento de resistencia armada á sublevación militar, pois as dilixencias practicadas distaban de confirmalo, aínda dando por boa a súa presenza no concello na noite do 22 de xullo, que tampouco estaba probada, e será negada polo mestre no só no sumario, senón tamén nas memorias publicadas en 1986, cando tal participación mesmo podería ser percibida como meritoria por moitos dos lectores e lectoras do seu libro. ${ }^{63} \mathrm{E}$ considerando que os feitos relatados podían constituír un delito de rebelión militar, previsto no artigo 237 do Código de Xustiza Militar e nos concordantes do bando que declaraba o estado de guerra, e que existían indicios de criminalidade no comportamento de Gregorio Sanz García, acordouse o seu procesamento e prisión incondicional.

${ }_{63}$ Uno de tantos, 72. 
Ao día seguinte foille comunicado o contido do auto ao procesado, que vestía traxe de pano de cor castaña, se cadra o mesmo que lle fixera o pai de Pardal ao mestre homónimo de "A lingua das bolboretas» e luciu Fernando Fernán Gómez na película baseada no relato de Manuel Rivas. Interrogado polo xuíz, reafirmouse na declaración prestada inicialmente, e preguntado se quería engadir algo máis, aproveitou a ocasión para declararse un "ardiente defensor del orden y del respeto a la Ley y a las Autoridades», como se evidenciara nun mitin electoral de Acción Popular que tivera lugar en 1933 no teatro de Ribadeo: cando un numeroso grupo de asistentes tentaba boicotear o acto, subiu espontaneamente ao escenario para recriminar a actuación dos alborotadores, e así o podían confirmar Antonio Pérez y Pérez, comerciante e directivo no seu día de Acción Popular, e Antonio Maseda Bouso, que fora un dos oradores e era agora vogal da Comisión de Xustiza da Xunta Técnica do Estado e delegado extraordinario para a Protección de Menores. A petición de novas probas obedecía, como comenta nas memorias, á pretensión de adiar o máis posíbel a vista do xuízo a que ía ser sometido, xa que as sentenzas tendían a ser algo menos malévolas consonte ían pasando os meses.

A primeira das testemuñas foi citada mediante exhorto ao xuíz de Ribadeo e a segunda a través dun xuíz burgalés, e ambos ratificaron plenamente as palabras do mestre e recoñeceron que grazas á súa intervención se conseguira realizar o mitin. 0 comerciante lembraba que Sanz recriminara o comportamento dos alborotadores na súa condición de "compañero", e que estes mesmo o alcumaron de "chaquetero». Maseda precisaba que se tratara dun mitin da "coalición de orden o de derechas", e que os elementos de esquerdas ocuparan con bastante antelación moitas das localidades do teatro co propósito de impedir a súa celebración, "y con la consigna de aplaudir únicamente, evitando gritos, insultos o agresiones, porque supondrían fundadamente que aun amparados por quienes entonces desempeñaban puestos en el Ayuntamiento y especialmente por el Alcalde, de llegar a vías de hecho, hubieran llevado la peor parte». E fora un señor, a quen os seus informantes de Ribadeo identificaban co procesado, 0 que se aproximara a el para que lle permitise dirixirse aos que non cesaban de aplaudir e pedirlles que deixasen falar os oradores, dando así «una prueba de cultura y tolerancia». Eses mesmos informantes tamén lle comunicaron que o procesado, "aunque de izquierdas, era persona correcta y tolerante». E concluía afirmando que non se precisaban máis evidencias sobre os feitos polos que se lle preguntaba, por seren de dominio público. ${ }^{64}$

Catro días despois da declaración anterior, Sanz solicitou prestar outra, que terá lugar o 13 de decembro de 1937. Aínda que o propósito fundamental seguía a ser o mesmo, adiar a vista da causa, tentaba asemade acumular probas que lle puidesen servir de descargo, polo que optou por incorporar ao proceso a súa traxectoria como mestre, á que as autoridades militares non semellaban atribuír moito mérito. Afirmou, en primeiro lugar, que a única vez que estivera no concello nas datas próximas á sublevación -a súa ter-

${ }^{64}$ En todo caso, a actuación do mestre tamén foi confirmada por Enrique López Galuá, párroco de Ribadeo, e por Pedro Llenderrozos López Sordo, propietario, que daquela residía en Trabada. 
minoloxía foi outra, claro - fora o 19 de xullo, domingo, en que houbera unha reunión do Consello Local de Ensino Primario para informar sobre a denuncia presentada contra unha mestra; nesa reunión actuara como secretario accidental, e o informe elaborado remitírase ao Consello Provincial. Polo demais, o día 22, ás horas en que era acusado de estar na casa consistorial, estaba no domicilio do seu amigo Domingo Sáez Fernández. Sobre a súa conduta moral podían testemuñar os pais e nais dos alumnos da súa escola, dos que cita catro e tres, respectivamente. Finalmente, e malia non ensinar a doutrina cristiá, por non lle estar permitido, si "enseñaba la práctica de las virtudes cristianas», e así se evidenciaba na súa asistencia, con boa parte do alumnado, á misa de aniversario celebrada pola alma da ex-alumna Julita Gatón Magadán, como podía corroborar a nai da nena. As testemuñas ás que apelaba sumaban oito, que se unían ás 20 que xa foran citadas para declarar.

Para comprobar o primeiro extremo, oficiouse ao Consello Provincial de Ensino Primario, que á súa vez solicitou información ao Consello Local de Ribadeo, segundo o cal non constaba no libro de actas ningunha sesión datada 019 de xullo. ${ }^{65}$ Con todo, o mestre insistirá nas súas memorias que tal reunión tivo lugar. ${ }^{66}$ É posíbel que se fixese un borrador e que, finalmente, dadas as circunstancias, non fose rexistrado no libro. Domíngo Sáez Fernández confirmou que estivera na súa casa o día 22, mais só durante uns quince minutos, entre as 21 e as 21.15, e descoñecía o que fixera antes e despois. Julia Magadán tamén corroborou as palabras do mestre.

Os declarantes non tiñan ningunha dúbida sobre a corrección moral do investigado, nin tampouco sobre a súa condición esquerdista. Na súa escola estaba ausente —por razóns legais, lembraban algunhas testemuñas- a relixión católica, mais non facía labor antirrelixioso nin ensinaba nada contrario aos bos costumes. Máis aínda, en opinión de Fernando Dapena, militar xubilado, «la moral que explicaba podía tenerse por perfectamente Católica", como puidera comprobar a través do seu neto. Como mestre particular ensinaba a relixión e a moral, de forma teórica e tamén práctica, e así o declaraba Francisca A. de García González, de cuxos fillos fora «preceptor exclusivo» ao longo de doce anos. De modo que todos os interrogados lle entregaban confiadamente os seus fillos, a non ser Eugenio López Yáñez, secretario do concello de Ribadeo: "Que dada la significación marxista del Gregorio Sanz García estima que, últimamente, no podía merecer confianza a ningún padre de familia Católico y español.»

\footnotetext{
${ }^{65}$ Gumersindo García Presno tamén cuestionará a existencia de tal reunión: «dada la efervescencia que reinaba en la Villa y especialmente entre los elementos del Frente Popular, ya que a aquella hora [noite do día 22 de xullo] comenzaron a aparecer los primeros milicianos rojos armados, no es de creer que se celebraran en el Ayuntamiento reuniones del Consejo local de primera Enseñanza, ni que nadie se preocupara por aquellos días y menos a aquellas horas de tales cuestiones." Mais aquel día e aquela hora non eran, como xa sabemos, os apuntados por Sanz. Pola súa parte, o comandante do posto da Garda Civil consignou no seu informe que a única reunión co propósito mencionado por Sanz tivera lugar o 14 de xuño nos locais da Agrupación Popular e que actuara como secretario José Rico.

${ }^{66}$ Uno de tantos, 13 e 81.
} 
O xuíz instrutor da causa remitiu un resumo das actuacións ao auditor de guerra 0 16 de xaneiro de 1938, e este acordou que se intensificase a investigación no tocante á asistencia do mestre ás reunións da Fronte Popular na casa consistorial de Ribadeo. En consecuencia, Hickman citou tres testemuñas —neste caso deberían prestar declaración no Xulgado Militar de Lugo e na súa presenza — para que ampliasen as súas declaracións. Unha delas foi Pablo de la Puente, alférez da Garda Civil a quen xa coñecemos, destinado daquela en Lugo, que se ratificou no seu anterior testemuño e engadiu que o procesado xa asistía antes do 18 de xullo ás reunións dos esquerdistas no concello:

Que el dicente cree que la opinión del Gregorio Sanz era atendida en las citadas reuniones y que le consideraba con autoridad suficiente para imponerlas. Que en la noche del veintiuno de Julio, encontrándose el que declara en el descanso de la escalera entre la Sala de Sesiones y la Secretaría del Ayuntamiento, salió de esta el Gregorio Sanz y al comenzar a bajar las escaleras salió de la Sala de Sesiones el conocido Manuel Pérez Prieto quien con las manos en la cabeza blasfemaba y decía «no se puede con ellos" refiriéndose a los de la Casa del Pueblo por lo que el que declara dirigiéndose a este como al Gregorio Sanz les dijo: «justo es que recojan Vs. el fruto de la cosecha que han sembrado", marchando escaleras abajo el Gregorio y penetrando el Médico en la Secretaría.

As outras dúas testemuñas foron Gumersindo García Presno, quen confirmou que o vira saír do concello a iso das once da noite do día 22 de xullo, e supuña que a súa presenza obedecería á pretensión de organizar a «resistencia» á entrada dos militares na vila, e José Antonio Lombardero Mon, que o vira entrar sobre as dez e descoñecía a hora á que saíra.

O xuíz militar solicitou, así mesmo, novos informes á Garda Civil de Ribadeo, cuxo comandante, o brigada Juan Veiga Cobas, subliña, en primeiro lugar, a intensa propaganda da Fronte Popular realizada polo procesado, que fixera «un verdadero derroche de sus relevantes dotes oratorias a favor de tan nefastas doctrinas». Tamén confirma a súa presenza no concello na noite do 22, cando menos até as 22.30 , e malia descoñecer o contido dos acordos adoptados na reunión mantida polos esquerdistas, o seu sentido podía deducirse das arengas que algúns dos seus líderes —exclúe a Sanz- fixeron deseguido desde os balcóns da casa consistorial, procurando convencer a xente da necesidade de «tomar las armas para oponerse al Movimiento Nacional, haciendo resaltar hipotéticas ayudas.» E proseguía:

Se ignora igualmente la tesis que el Sr. Sanz pudo haber sostenido en la reunión, [pero] lo que sí es evidente es que no dio por conclusas sus relaciones con los elementos dirijentes [sic] del frente popular ya que próximamente a las 13.30 del día siguiente o sea cuando ya se tenía conocimiento en la villa que la columna libertadora se aproximaba, momentos antes de su entrada, fue visto al lado del médico, también significado dirijente [sic] huido declarado rebelde Manuel Pérez Prieto en el balcón de la casa de este, vistiendo bata blanca igual que el médico. ${ }^{67}$ Es creencia bastante generalizada de que en el grupo de dirigentes izquierdistas de esta villa representa el Sr. Sanz la moderación, teniendo origen esta especie a juicio del que suscribe, en la exquisita corrección de que dicho señor rodeaba todos sus actos.

\footnotetext{
${ }^{67} \mathrm{O}$ médico pediulle que 0 acompañase á súa clínica e o axudase a curar os feridos que previsibelmente se producirían no curso dos enfrontamentos que se estaban a producir. Así o fixo, e vestido con bata branca presenciou desde a galería da casa de Pérez Prieto algúns dos incidentes (ibídem, 16).
} 
Animado polo mesmo propósito que en ocasións anteriores, o 23 de febreiro de 1938 don Gregorio solicitou que se tomase declaración sobre diversos extremos a seis persoas máis e se pedisen informes a outras tantas autoridades.

Solicitaba que se lle preguntase a César García González, de cuxo sogro era «secretario particular», se entre as 10 e as 11 da noite do día 22 de xullo estivera no seu domicilio para tratar asuntos relativos á condición de tal; se ao día seguinte o agora procesado cualificara o que ocorría en Ribadeo "de ridiculez y de falta de autoridad» e, finalmente, se estaba ao tanto do incidente que tivera con Gumersindo García Presno «en ocasión en que este, que se hallaba embriagado, faltó a una hermana política del que suscribe, y si oyó manifestaciones del D. Gumersindo sobre sus deseos de venganza», todo o cal resultou confirmado pola testemuña convocada. ${ }^{68} \mathrm{~A}$ Ramón Fernández de Soto, secretario do Instituto, debía preguntárselle se era certo que, ao comentar o asasinato de Calvo Sotelo, manifestara «su sentimiento no solo por la muerte de tan gran español, sino porque la forma en que fue realizada significaba la deshonra del Gobierno y el descrédito de la República», circunstancia que tamén foi acreditada polo interpelado. $\mathrm{O}$ sereno Jesús Gómez y Gómez testemuñou que non vira entrar nin saír o mestre da casa consistorial desde as 22 horas do día 22 até as seis do 23, e outro tanto afirmou o garda municipal Agustín Martínez Tellado para o intervalo comprendido entre a unha da madrugada do 23 e a hora en que rematou a súa quenda, e que antes desa hora nada sabia, se ben un sereno chamado Genaro, que estivera de servizo, comentoulle que tampouco o vira entrar. A Enrique López Galuá, párroco e profesor do Instituto de Ribadeo, pedíalle que informase se os seus alumnos da escola preparatoria «recibieron en la referida Escuela sólidos conocimientos de Religión e Historia Sagrada y adquirieron la práctica de las virtudes cristianas», e se estes, acompañados do seu profesor, asistiran á misa de aniversario por unha ex-alumna. Sobre o primeiro extremo o párroco declarará que a formación relixiosa «era nula, pues él fue siempre de tendencias marcadamente laicas", e sobre o segundo, aínda que non estaba presente, "cree perfectamente posible que haya asistido, pues le gustaba cubrir las formas y ser complaciente y desde luego no tenía repugnancia a oficios religiosos cuando deberes sociales se lo imponían.» ${ }^{69} \mathrm{~A}$ última testemuña á que apelaba era Valentín Jiménez Moro, aínda que finalmente renunciou á súa comparecencia.

O mestre quería que o alcalde, o comandante do posto da Garda Civil e o xefe de Falanxe de Ribadeo desen fe de que nas súas intervencións públicas nunca defendera «ideas subversivas ni disolventes», e si, pola contra, «el amor al Trabajo y el respeto a la Ley y a las Autoridades; dedicándose de manera especialísima a la defensa de la Escuela

\footnotetext{
${ }^{68}$ Esta testemuña declarou que existía "enemistad manifesta» entre García Presno e Sanz García desde o día en que este lle pegou a aquel unhas labazadas por mor do devandito incidente.

${ }^{69} \mathrm{O}$ mestre tivo a oportunidade de revisar no seu momento o sumario e de tomar nota dalgunhas declaracións que lle resultaban especialmente amargas e inxustas. A propósito das palabras do párroco escribe: "Pero si la Misa se celebró el 28 de junio de 1936 y la difunta era huérfana de un Guardia Civil muerto en Asturias en Octubre de 1934, ¿dónde están las conveniencias sociales para un Maestro Nacional que con todos sus alumnos va desde la Escuela a la Iglesia y desde la Iglesia a la Escuela cuando el mismo Párroco dice que la Iglesia era oficialmente perseguida?...” (Uno de tantos, 80).
} 
Nacional, exhortando a los padres que enviasen sus hijos a la misma como medio de ayudar a hacerlos ciudadanos honrados y útiles a la Patria y solicitando siempre la creación en Ribadeo de más escuelas, por existir solamente una de niñas y dos de niños para una población de mas de tres mil habitantes." A Garda Civil afirmará que o seu esquerdismo era o propio dun home «templado» e que nunca predicara a violencia, e a Falanxe, que difundira a ideoloxía socialista de forma morna, pero que nos períodos previos ás eleccións, «si bien no predicó la violencia, envenenó los campesinos y obreros con sus promesas contra la propiedad particular.» A alcaldía tamén apreciaba dúas fases na súa evolución: inicialmente practicaba a moderación e apostaba

por los procedimientos evolutivos, mas últimamente, cuando el marxismo era dueño de los resortes del poder, el Sanz García cambió y si bien no aconsejaba a sus oyentes la violencia por las armas para la consecución de las reformas que ellos llamaban reivindicadoras de la clase trabajadora, se expresaba en términos de exaltada rebeldía, típica del orador marxista, que la inculta masa que le escuchaba, interpretaba, quizá exagerando, con [como] una incitación a que todos los medios eran buenos con tal de llegar al fin.

O procesado tamén conseguiu informes favorábeis de Ayllón, o concello onde nacera, e solicitou que se unisen á causa. $O$ alcalde e o xefe de Falanxe certificaron a súa boa conduta, mentres que o párroco se desfacía en gabanzas: pertencía a unha familia modélica en todos os aspectos, cumpría cos seus deberes relixiosos, tiña grande amizade coas monxas do convento existente na vila e o verán anterior mesmo lle axudara a localizar e copiar certos documentos que precisaba «para un asunto eclesiástico en contra de los del frente popular».

Pola súa parte, o brigada da Garda Civil Pablo de la Puente compareceu no Xulgado Militar de Lugo para rectificar a declaración anterior, pois confundira a Gregorio Sanz García con César Margolles de la Vega. Fora esta a persoa coa que coincidira no concello o 21 de xullo e a ela se quería referir na súa declaración. César Margolles, mestre tamén, conseguiu fuxir da represión en Ribadeo e será finalmente asasinado en Asturias. ${ }^{70}$

O 16 de marzo de 1938 o xuíz fixo chegar un novo resumo das dilixencias ao auditor, que considerou completo o sumario e acordou remitilo ao plenario. ${ }^{71}$ Previamente debía ser entregado ao fiscal, para que realizase a cualificación provisoria dos feitos. Ao entender deste, quedaba probado que Gregorio Sanz, home culto e de grandes dotes oratorias,

\footnotetext{
${ }^{70}$ Carlos Nuevo Cal, "A impunidade e a represión fascista nas terras da Mariña Luguesa», en Os nomes do terror: Galiza 1936: os verdugos que nunca existiron, ed. Xosé Ramón Ermida Meilán e outros (Santiago de Compostela: Sermos Galiza, 2017), 115-134. César Margolles si que tivo un papel destacado na organización da resistencia (Lombardero, Sociedade Ribadense, 31-33).

${ }^{71}$ Por esas datas, o xuíz chamouno para facerlle saber que a súa situación era moi comprometida e mais para recriminarlle que non se limitara a exercer o seu traballo de mestre. O procesado retrucou que todas as súas actividades se axustaran á legalidade vixente, e que «como Maestro Nacional habría dejado de cumplir con mi deber si me hubiera limitado a enseñar a los niños a leer, escribir y contar», xa que "la verdadera misión del Maestro es la de educar, la de ayudar a formar ciudadanos capacitados para el progreso y bienestar de la nación de que forman parte.» E isto, debido ao atraso da sociedade española, requiría actuar tamén sobre os pais (Uno de tantos, 73-75).
} 
tomara parte en «todos los mítines de carácter marxista, que pomposamente llamaban «antifascistas» », organizados en Ribadeo durante a República, e que a súa actuación fora «templada y evolutiva» nun primeiro momento e «marcadamente extremista» despois, "si bien no llegaba a los extremos de violencia, pero sí pudiéndosele considerar envenenador de la masa campesina.» Proclamado o estado de guerra, reunírase no concello coas xentes de esquerda para organizaren a resistencia ao Exército. O procesado incorrera, xa que logo, no delito de rebelión militar, polo que propuña para el a «prisión perpetua a muerte».

O xuíz ofreceu a Sanz a relación de oficiais que podían encargarse da súa defensa, e resultou elixido o alférez de Infantaría Manuel Souto Romero. Este asistiu á lectura de cargos, que se fixo deseguido, e cos que o procesado non se conformou. Preguntado sobre se quería ampliar ou rectificar as declaracións realizadas dixo que si, pero que o faría na vista da causa e en resposta ás preguntas do seu defensor, e propuxo como testemuñas a César García González e Marcelino Menéndez, ambos de Ribadeo, Guillermo Cisneros Fernández, de Vilanova de Lourenzá, e Desiderio Gutiérrez de Castro, profesor do Instituto de Ourense. Advertíuselle que a súa asistencia sería voluntaria, xa que o xulgado só citaba os veciños da localidade.

A data fixada para o consello de guerra foi o 7 de abril de 1938, e tivo como escenario o edificio da Deputación Provincial. ${ }^{72}$ Unha vez lidos os cargos, o fiscal interrogou ao alférez Pablo de la Puente, unha das testemuñas que el citara - a outra, Gumersindo García Presno, achegou un certificado de padecer "cistite aguda» para xustificar a súa ausencia-. O alférez reiterou que, malia coñecer a Sanz, que lle merecía un bo concepto, o confundira con César Margolles debido «a la efervescencia y nerviosismo propios de aquellos momentos", e o fiscal retrucou que, caso de o coñecer, non era posíbel tal confusión, polo que pediu que constase en acta a contradición en que incorría o membro da Benemérita. ${ }^{73}$ $\mathrm{O}$ defensor interrogou a Guillermo Cisneros Fernández, que cualificou a Sanz de bo cidadán e bo mestre, e confirmou a súa inimizade con García Presno debido ao incidente xa sinalado. Interrogado polo fiscal sobre as actividades políticas do procesado, dixo que as

\footnotetext{
${ }^{72} \mathrm{Na}$ noite previa á vista da causa, e temendo ser condenado a morte, escribiu cartas de despedida para a muller, o pai, a nai e a irmá e o irmán. Reproducimos un anaco desta última, que fai referencia á súa actuación como mestre: «Mañana voy a presentarme ante el Tribunal militar que ha de juzgarme. Como ya más adelante te enterarás se me hacen cargos bastante graves, aunque sin fundamento real pues jamás llegué a realizar los hechos que se me imputan. Los que tienen parte de veracidad se refieren a mis propagandas; pero bien sabes que por mi manera de pensar, por mi modo de vivir, nunca he sido extremista ni mucho menos y que he defendido la Escuela considerándola como el fundamento de la prosperidad de España. Tengo la conciencia muy tranquila porque, jamás, a sabiendas, he dado lugar a que nadie sufriera el menor perjuicio por culpa mía, y en la Escuela y fuera de ella he procurado cumplir lo mejor posible con mi obligación, señalando a mis alumnos el camino del amor al trabajo, del respeto a la Ley, de la obediencia a las Autoridades y de la práctica de las virtudes cristianas, aun en los últimos tiempos de laicismo oficial» (ibídem, 90).

${ }^{73}$ Aínda que non se recolle no sumario da causa, o tenente auditor espetoulle: ou vostede mentiu na primeira declaración ou mentiu na segunda. 0 mestre declarábase desconcertado pola actuación do brigada, que primeiro informara negativamente sobre el, e mesmo preguntara aos milicianos que o custodiaban no cárcere de Mondoñedo se aínda non fora fusilado, e posteriormente rectificara as súas declaracións, expóndose á censura dos seus superiores. Cando puido ver a faciana do garda civil, Sanz apreciou nela «miedo a ulteriores acciones de la Justicia Militar» (ibídem, 60-61, 81 e 95-97).
} 
ignoraba, e que nos mitins en que participara se limitara a defender a institución escolar. 0 avogado renunciou ao interrogatorio do resto das testemuñas.

Deseguido suspendeuse a sesión por cinco minutos. Retomada esta, interveu o fiscal para resumir os feitos e solicitar cadea perpetua, ${ }^{74} \mathrm{e} o$ defensor para subliñar a moderación do seu defendido, negar a súa asistencia á reunión do 21 de xullo de 1936 na casa consistorial de Ribadeo e pedir a absolución. ${ }^{75}$ Gregorio Sanz, convidado a falar no seu descargo, optou por non dicir nada. Total para que.

A sentenza, encabezada pola habitual diatriba contra a Fronte Popular, ${ }^{76}$ considerou probado que o mestre, de boa conduta no ámbito privado, contribuíra durante a República a propagar a ideoloxía de esquerdas, auxiliado pola súa notábel elocuencia —as súas dotes expresivas e persuasivas reitéranse no sumario-, e nos días posteriores ao 18 de xullo asistira a unha reunión dos dirixentes esquerdistas para organizaren a resistencia ao Exército, "sin que se haya podido acreditar que el procesado tomase parte en los acuerdos que se adoptaron pero que sí estuvo a disposición de aquéllos con el propósito de ayudarles y por consecuencia de ayudar como ayudó a la causa rebelde.» $E$ dado que tales feitos eran constitutivos dun delito de «auxilio á rebelión» —recollido no artigo 240 do Código de Xustiza Militar - por parte do procesado, en quen concorría a «perversidad», evidenciada nos seus antecedentes esquerdistas,

FALLAMOS que debemos condenar y condenamos al procesado paisano GREGORIO SANZ GARCÍA como autor de un delito de Auxilio a la Rebelión con apreciación de su perversidad a la pena de VEINTE AÑOS DE RECLUSIÓN TEMPORAL con la accesoria de inhabilitación absoluta durante el tiempo de la condena y abono a fines de cumplimiento de la totalidad de la prisión preventiva sufrida.

O auditor de guerra propuxo ao xefe da Oitava Rexión Militar que se aprobase a sentenza, como así se fixo catro días despois de celebrado o xuízo. A Comisión Central de Exame de Penas acordou 028 de outubro de 1940 que a pena inicial fose conmutada por seis anos e un día de prisión maior —a Provincial propuña que fosen oito—, e o 12 de marzo de 1941 concedéuselle ao preso a liberdade condicional por boa conduta. Medio século

\footnotetext{
${ }^{74}$ Sanz escribe que o fiscal «empezó a dedicar sorprendentes elogios a mi persona, destacando mi preparación cultural, mi prestigio profesional, mi amor a la enseñanza, mi influencia sobre los compañeros de profesión, el poder de sugestión que tenía para con mis alumnos", mais que tales calidades estiveran ao servizo do mal, polo que solicitaba a cadea perpetua, que o condenado asumiu como un mal menor (ibídem, 97-98).

${ }^{75} \mathrm{~A}$ intervención do defensor foi penosa, pois comezou lamentando que o fiscal pedise para o seu defendido a pena de morte... "¿Tan torpe era que no se había enterado de la petición fiscal?» (ibídem, 100-101). E iso que o propio mestre lle entregara un borrador do esquema argumental que se podería utilizar na súa defensa e a familia de Sanz un discurso redactado por un experto na materia que debía ser lido "sin quitar ni añadir nada» (ibídem, 82).

${ }^{76}$ "Que el día 18 de Julio de 1.936, el Ejército español recogiendo y haciéndo[se] intérprete del sentir nacional, se hizo cargo del poder que venía siendo detentado por el denominado Frente Popular con su Gobierno perseguidor de lo genuinamente español y que era fiel vasallo de los dictados extranjeros, encaminados a destruir el arsenal de virtudes, cualidades y conquistas del pueblo español a través de los siglos, viéndose desde [un] principio el poder nacional atacado por los españoles de la antipatria que aún en algunas regiones hostilizan con las armas y bajo mando Militar a las fuerzas del Ejército mantenedoras de aquel.»
} 
despois, o noso home asinou unha instancia en que solicitaba acollerse aos beneficios da amnistía, "graza» que lle foi concedida.

\section{Consideracións finais}

Conseguida a liberdade, había que buscar unha ocupación que permitise gañar a vida, da que aínda restaban moitos anos por vivir. Logo de traballar durante un tempo nunha fábrica de embutidos de Guitiriz, exerceu, como xa sabemos, o ensino particular na cidade de Lugo, primeiro no Colexio Balmes e logo por conta propia. Ao ser readmitido no maxisterio asignóuselle unha interinidade na escola de Covas (Viveiro). En 1960 aprobou o concurso-oposición para cidades de máis de 10000 habitantes e foi destinado a Vigo, onde se xubilou cando el e o século cumpriron os 70 anos. A súa derradeira lección versou, claro está, sobre a "escola pública», segundo nos conta Víctor Moro, presente no acto, aínda que ao mellor do que realmente falou foi da «escola nacional».

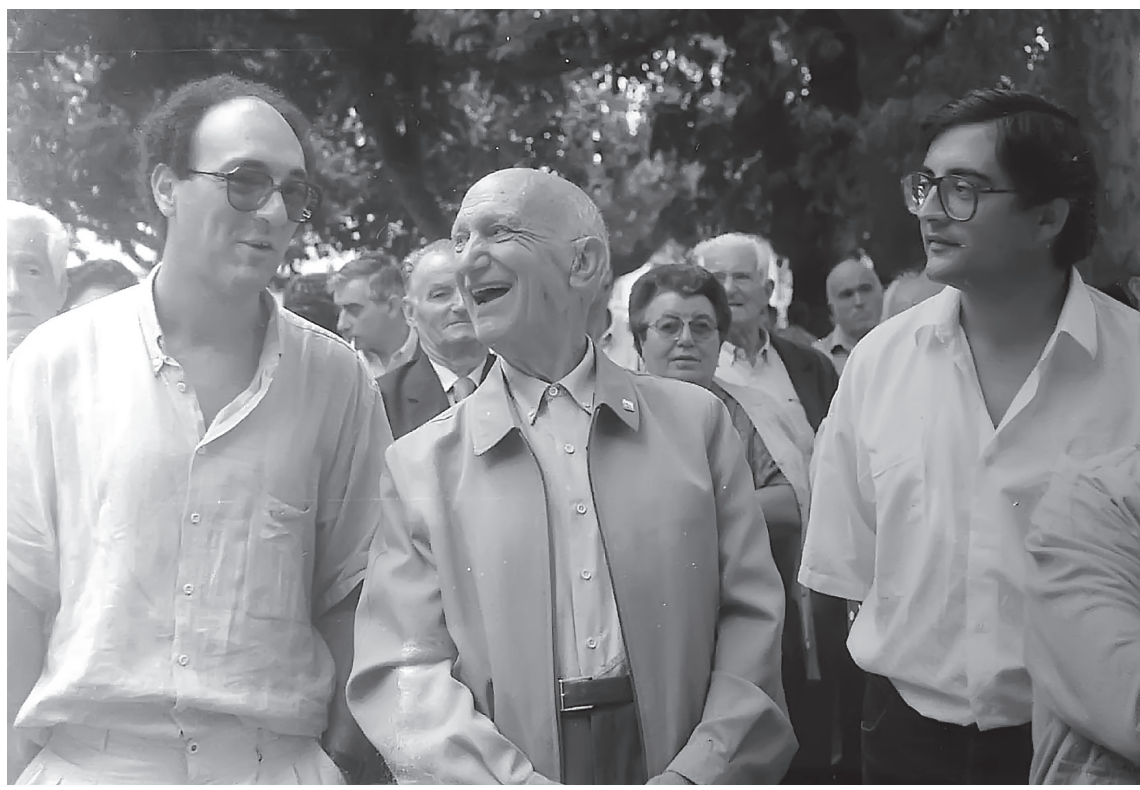

Don Gregorio acompañado por Carlos Ávarez Lebredo e José María Lombardero Rico (fotografía realizada por Aida Pazos en 1988).

Nos últimos anos da súa vida regresou a Ribadeo, onde retomou o labor de dinamización cultural realizado nas décadas de 1920 e 1930. Referirémonos só a unha conferencia pronunciada na Agrupación Cultural Francisco Lanza en 1981. Tratou, ao dicir da prensa, sobre a evolución da "escuela pública o escuela nacional», e o orador subliñou 0 alcance que tivera unha medida adoptada en 1901: a incorporación dos salarios do maxisterio aos orzamentos xerais do Estado. Até ese momento o pagamento realizábano os concellos, 
polo que «los maestros estaban sometidos al capricho de los alcaldes, del cacique 0 de las personas influyentes de la localidad. ${ }^{77}$ A partir de entón irán adquirindo unha autonomía que os liberará das dependencias locais e os converterá, paseniñamente, en mestres nacionais - Sanz seguramente escribiría Mestres Nacionais-. Tamén será por esas datas cando o Estado pretenderá intensificar a función nacionalizadora da escola primaria e a converterá expresamente nunha «Escola Nacional». ${ }^{78}$

Don Gregorio foi obxecto de diversos recoñecementos, uns en vida e outros unha vez morto. Limitarémonos a deixar constancia da súa designación como pregoeiro das festas de Ribadeo (1986) e como socio de honra de Nova Escola Galega (1993), e da asignación do seu nome ao colexio público de Ribadeo (1994) e a unha escola infantil na cidade de Lugo (2010). Nas súas memorias escribiu: "cuando las pasiones, las malas pasiones que ahora infectan el ambiente, hayan remitido, resplandecerá la verdad y se hará la verdadera justicia a cuantos ahora somos perseguidos. " $^{79}$ Unha xustiza que será limitada, serodia e graciosa, malia os esforzos dalgúns - como Isaac Díaz Pardo, editor de Uno de tantospor reparar, na medida do posíbel, a dor causada polo terror.

\footnotetext{
${ }_{77}^{7}$ La Voz de Galicia, 28 de xullo de 1981, crónica de José A. Fariñas.

${ }^{78}$ Narciso de Gabriel, "Caciques, schools and schoolteachers in Spain from the mid-nineteenth century to the 1920's", Paedagogica Historica. International Journal of History of Educacion, 54-5 (2018), 545-563.

79 Uno de tantos, 75.
} 
Docrmentos 
